\title{
NAFTA, Alberta OIL SANDS Royalties, AND CHANGE: YES WE CAN?
}

\author{
BERNARD J. ROTH*
}

The Government of Alberta has recently announced that it intends to increase oil sands royalty rates. This article reviews these proposed changes to determine if they comply with the investment protection obligations Canada assumed under c. 11 of the North American Free Trade Agreement (NAFTA). In addition to ensuring non-discriminatory treatment of investors, $c$. 11 of the NAFTA prohibits expropriation of investments without compensation. What constitutes expropriation under the NAFTA may be broader than the expropriation protection under either American or Canadian domestic law. The result is that American investors in Canada may have greater protection against expropriation than Canadian investors in Alberta. Likewise, Canadian investors in the United States may also be in a preferred position relative to American investors in their own country. The article concludes that the Government of Alberta may have to compensate U.S. investors in Alberta's oil sands if it carries through with the oil sands royalty changes it has announced.
Le gouvernement de l'Alberta vient d'annoncer qu'il a l'intention de hausser les redevances des sables bitumineux. Cet article examine les changements envisagés afin de déterminer s'ils sont conformes aux obligations de protection des investissements dont le Canada est responsable en vertu de l'article 11 de l'Accord de libre-échange nord-américain (ALENA). En plus de veiller à ce que les investisseurs ne fassent pas l'objet de discrimination, l'article 11 de l'ALENA interdit l'expropriation d'investissements sans dédommagement. La définition d'expropriation au sens de l'ALENA peut être plus large que la définition en vertu des lois nationales américaines ou canadiennes. Par conséquent, les investisseurs américains pourraient être mieux protégés de l'expropriation que les investisseurs canadiens en Alberta. Dans le même ordre d'idée, les investisseurs canadiens aux États-Unis pourraient également jouir d'une situation privilégiée à l'égard des investisseurs américains dans leur propre pays. L'article conclut que le gouvernement de l'Alberta pourrait devoir dédommager les investisseurs américains des sables bitumineux albertains si les changements annoncés sont mis en place.

\section{TABLE OF CONTENTS}

I. INTRODUCTION . . . . . . . . . . . . . . . . . . . . . . . . . . . . . . 336

II. OIL SANDS INVESTMENT $\ldots \ldots \ldots \ldots \ldots \ldots$. . . . . . . . . . . . . . . 340

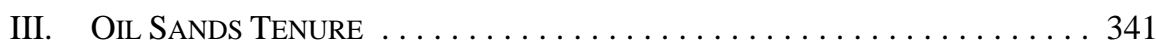

IV. OIL SANDS Royalty REVIEW . . . . . . . . . . . . . . . . . . . . . 344

V. CanAdian LaW . . . . . . . . . . . . . . . . . . . . 347

A. Legal Nature of CROWN Oil SANDS LeAse

AND RESERVED ROYALTY . . . . . . . . . . . . . . . . . . . . 347

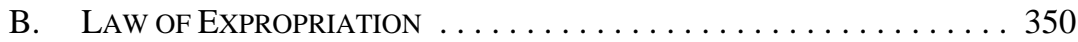

VI. AMERICAN TAKINGS LAW . . . . . . . . . . . . . . . 358

VII. NORTH AMERICAN FREE TRADE AGREEMENT . . . . . . . . . . . . . . . 362

A. PROVISIONS OF THE NORTH AMERICAN

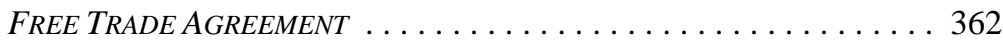

Partner, Fraser Milner Casgrain LLP (FMC). The author practices energy and environmental law at FMC's Calgary office. The author wishes to thank the following articling students, who researched various topics for this article: Derek Pontin (Canadian law); Jordan Milne (American law of takings); Janet Nystedt (international law); and Brian Woods (various factual details regarding investment in Alberta's Oil Sands). 
B. NORTH AMERICAN FREE TRADE AGREEMENT

ARBITRAL AWARDS . . . . . . . . . . . . . . . . . . . . 365

C. TAX Vs. ROYALTY . . . . . . . . . . . . . . . . . . . 375

VIII. CONCLUSION .............................. 376

$[\mathrm{N}]$ othing can withstand the power of millions of voices calling for change. ${ }^{1}$

\section{INTRODUCTION}

On 18 September 2007, the Alberta Royalty Review Panel issued a report entitled Our Fair Share. ${ }^{2}$ The report recommended substantial increases in royalty rates and new taxes for Alberta's oil sands. Albertans overwhelmingly agreed with the recommendations. There was little political debate as to whether royalties should be increased. The only issue was by how much.

Based on past experience, the voices calling for change could have been anticipated. The royalty review was undertaken following a period of increasing world oil prices. Other jurisdictions, such as the United Kingdom, Russia, Venezuela, and Bolivia, had already responded to rising oil prices by substantially increasing the economic rent on their oil and gas resources. The Royalty Review Panel, in fact, relied on increasing takes elsewhere in asserting that Albertans were not receiving their fair share.

It was not only international experience that foreshadowed the call for change. Canada had its own history with governments demanding their fair share in response to past increases in world oil prices. There are at least two noteworthy examples. The first arose out of the 1973 Arab Oil Embargo. World oil prices quadrupled, rising from $\$ 3$ a barrel to $\$ 12$ a barrel. The province of Saskatchewan reacted by adopting a tax on freehold production and a royalty surcharge on Crown land to capture "windfall profits" from oil and gas producers. Industry successfully challenged the constitutional authority of the Government of Saskatchewan to implement its scheme. In Canadian Industrial Gas \& Oil Ltd. v. Saskatchewan, ${ }^{3}$ a majority of the Supreme Court of Canada held that Saskatchewan's royalty increase constituted indirect taxation. Since Canadian provinces were, at the time, limited to direct taxation, the majority of the Court held that Saskatchewan could not implement its scheme. The decision is reflective of a line of Supreme Court of Canada decisions in which repugnant legislative schemes were struck down using Canada's constitutional divisions of powers. ${ }^{4}$ The repugnancy that the Supreme Court of Canada may have been addressing in CIGOL was Saskatchewan's use of its powers of expropriation without compensation.

$1 \quad$ Barack Obama, "Remarks of Senator Barack Obama: New Hampshire Primary (commonly referred to as the "Yes We Can" speech, 8 January 2008), online: Organizing for America <http://www.barack obama.com/2008/01/08/remarks_of_senator_barack_obam_82.php>.

2 Our Fair Share: Report of the Alberta Royalty Review Panel (18 September 2007), online: Alberta Royalty Review <http://www.albertaroyaltyreview.ca/panel/final_report.pdf> [Our Fair Share].

3 [1978] 2 S.C.R. 545 [CIGOL].

$4 \quad$ Patrick J. Monahan, “Is the Pearson Airport Legislation Unconstitutional?: The Rule of Law as a Limit on Contract Repudiation by Government” (1995) 33 Osgoode Hall L.J. 411 at 435. 
The second example of a Canadian government demanding its fair share resulted from an oil price spike in 1980. Oil prices more than tripled from 1973 levels to \$38 a barrel. This time it was the Government of Canada demanding a fair share. The Our Fair Share document was entitled The National Energy Program, $1980 .^{5}$ The fair share that the Government of Canada was demanding came at the expense of the provinces, and mainly Alberta. ${ }^{6}$ The Government of Canada proposed taking its fair share directly from the provinces because it believed it would have been "unfair and ill advised" if the burden were to be placed on industry. ${ }^{7}$ The Government of Alberta challenged the constitutional authority of the federal government to implement the National Energy Program (NEP) with respect to Alberta's natural gas resources. Alberta made its case based on the constitutional prohibition against federal and provincial governments taxing one another's property. ${ }^{8}$ In Natural Gas Tax,${ }^{9}$ a majority of the Supreme Court of Canada held that the Government of Canada could not extract its fair share from Alberta's natural gas resources. The constitutional division of powers stood in the way of millions of voices from eastern Canada calling for change.

To suggest that the NEP was fair to industry would be wrong. There were many facets of the NEP beyond the natural gas export tax. The NEP was replete with other types of export taxes and controls on domestic commodity pricing that had significant impacts on industry. The NEP also had a Crown share back-in on Canada lands. As will be explained later, this aspect of the NEP is a close parallel to Alberta's increased oil sands royalty. All of these measures took their toll on industry, and with it, investment in the development of Canada's oil and gas resources. The NEP challenged Canada's reputation as a secure place to invest and it challenged the ability of the United States to rely upon Canada as a secure source of oil and gas supply in an increasingly insecure world.

Although the NEP has lived long in the memories of Albertans, it did not live long in fact. Rapid declines in oil prices and a change in government at the federal level resulted in the dismantling of the NEP. Between 1984 and 1987, Canadian governments deregulated the energy market and the federal government commenced negotiating a free trade agreement with the U.S. ${ }^{10}$ Through free trade, Canada would obtain secure access to the largest market in the world on what was hoped to be an uninterrupted basis. ${ }^{11}$ The U.S. would obtain secure access to Canada's considerable energy resources through free trade in energy goods and investment in Canada without discrimination and uncompensated expropriation.

Energy, Mines and Resources Canada, The National Energy Program, 1980 (Ottawa: Minister of Supply and Services Canada, 1980) [NEP 1980].

$6 \quad$ At the time, Alberta received over 80 percent of all oil and natural gas revenues relative to all other Canadian provinces. See Re Proposed Federal Tax on Exported Natural Gas, [1982] 1 S.C.R. 1004 at para. 108. [Natural Gas Tax].

NEP 1980, supra note 5 at 15.

Constitution Act, 1982, s. 125, being Schedule B to the Canada Act 1982 (U.K.), 1982, c. 11.

Supra note 6.

Allan L. McLarty \& David A. Holgate, "Natural Gas Deregulation: Review and Perspective” (1987) 26 Alta. L. Rev. 1; C. Kemm Yates, "NAFTA and Canada-United States Trade in Natural Gas: Will the Regulators Let it Make a Difference?” [1994] 6 Oil and Gas Law and Taxation Review 171.

11 There are some difficult trade issues that the NAFTA has not been able to resolve. The softwood lumber case is one example: see Linda C. Reif, "Desperate Softwood Lumber Companies?: The Canada-U.S. Softwood Lumber Dispute and NAFTA Chapter 11” (2007) 45 Alta. L. Rev. 357. 
The relatively short period between the enactment of the NEP and the negotiation of the Canada-United States Free Trade Agreement ${ }^{12}$ also saw significant developments on the domestic constitutional front. Prior to 1982, Canada was not, technically, a sovereign country. Our Constitution required amendment by the Parliament of the U.K. in order to effect constitutional changes. In 1981, the Government of Canada was anxious to patriate the Canadian Constitution and put the power to amend it in the hands of the Parliament of Canada and provincial legislatures. The Government of Canada also wanted to give Canadians a charter of rights and freedoms that would protect certain fundamental civil rights. Prior attempts by the federal government to patriate the Constitution had been met with opposition from some provinces. However, following the NEP, a deal was struck between the federal government and the provinces. Canada's resource-rich western provinces, led by Alberta, were not content with the limitations placed upon the development of their natural resources. A prime source of discontent was the Supreme Court of Canada's CIGOL decision, which concluded that provinces did not have the power of indirect taxation over their own resources. In order to obtain sufficient support from the provinces to proceed with the patriation process, the federal government agreed to a significant amendment to the distribution of powers. This amendment, known as s. 92A, confirms that provincial governments have considerable powers over their non-renewable natural resources, including the oil and gas trade. Section 92A provides provincial governments with clear powers to enact laws regarding interprovincial trade in non-renewable natural resources and it gives them the power of indirect taxation over these resources. Section 92A does not, however, provide provincial governments with any powers over international trade. ${ }^{13}$

Although the provinces agreed to accept the Canadian Charter of Rights and Freedoms, ${ }^{14}$ they were not prepared to constitutionally protect property rights. ${ }^{15}$ Provinces would have had the most to lose by providing such protection. The general provincial power over property and civil rights and the specific powers in respect of their natural resources would have been impacted. The provinces were apparently unwilling to relinquish these powers. They had just won the right to tax resources indirectly. They did not want to diminish that right by placing constitutional limitations on their ability to expropriate them.

At the same time that the federal government was negotiating its constitutional bargain with the provinces, the impetus behind the development of the North American Free Trade Agreement Between the Government of Canada, the Government of Mexico and the Government of the United States ${ }^{16}$ was playing out in Mexico. The oil price spike that was behind the NEP had led Mexico to invest heavily in increasing its oil production. In 1938, Mexico had nationalized its oil and gas industry. Unlike Canada’s oil and gas industry, Mexico's petroleum resources were being developed using public, rather than private, capital. Mexico debt financed this capital and relied on oil and gas revenues to meet its

122 January 1988, Can. T.S. 1989 No. 3, 27 I.L.M. 281 (entered into force 1 January 1989) [CUSFTA].

13 For a discussion of s. 92A of the Constitution Act, 1867 (U.K.), 30 \& 31 Vict., c. 3, reprinted in R.S.C. 1985, App. II, No. 5, see William D. Moull, “Section 92A of the Constitution Act, 1867” (1983) 61 Can. Bar Rev. 715.

14 Part I of the Constitution Act, 1982 being Schedule B to the Canada Act 1982 (U.K.), 1982, c.11.

15 Donald S. Macdonald, “Chapter 11 of NAFTA: What are the Implications for Sovereignty?” (1998) 24 Can.-U.S.L.J. 281 at 282.

1617 December 1992, Can. T.S. 1994 No. 2, 32 I.L.M. 289 (entered into force 1 January 1994) [NAFTA]. 
financing obligations. When oil prices collapsed in the 1980s, Mexico defaulted on its debt obligations and a financial crisis ensued that eventually led Mexico to approach the U.S. seeking a free trade deal. ${ }^{17}$ The purpose of free trade from Mexico's perspective was to attract foreign investment. The negotiations were complicated. Following its revolution in the early part of the twentieth century, Mexico adopted a Constitution that incorporated the Calvo Doctrine. ${ }^{18}$ Under the Mexican Constitution, all foreign investors had to agree to submit to domestic law and to be treated as Mexican nationals. They could not call upon their governments for diplomatic or military protection of their property. ${ }^{19}$

At one point prior to its nationalization, the Mexican petroleum industry was the second largest source of oil production in the world. ${ }^{20}$ This production resulted from the significant presence of American oil companies in Mexico. Following the expropriation of these companies' Mexican assets in 1938, a long diplomatic exchange occurred between the U.S. and Mexico. Through what became known as the Hull Formula, the U.S. demanded "prompt, just, and adequate compensation" for American oil company assets. ${ }^{21}$ Mexico responded with the Calvo Doctrine. Over time, Mexico ended up paying substantial compensation. ${ }^{22}$

The NAFTA is closely modeled after the CUSFTA. ${ }^{23}$ The substantive obligations of the CUSFTA do not vary significantly from those under the NAFTA. However, with respect to the process of protecting foreign investments, the U.S. demanded that the NAFTA investors have direct recourse to enforce their investment rights pursuant to international commercial arbitration proceedings. Interestingly, the U.S. was successful in negotiating the right of direct investor action; however, these rights did not apply to Mexico's oil and gas resources. Mexico was able to negotiate a reservation of its oil and gas industry from both the trade and investment provisions of the NAFTA. ${ }^{24}$ These reservations maintain complete Mexican sovereignty over its oil and gas resources. Such is not the case for Canada. The few reservations that Canada maintained under the CUSFTA were largely eliminated by the

Rachel D. Edsall, "Indirect Expropriation under NAFTA and DR-CAFTA: Potential Inconsistencies in the Treatment of State Public Welfare Regulations” (2006) 86 B.U.L. Rev. 931 at 933.

Calvo Doctrine is a foreign policy doctrine developed by Carlos Calvo. See Denise Manning-Cabrol, "The Imminent Death of the Calvo Clause and the Rebirth of the Calvo Principle: Equality of Foreign and National Investors” (1995) 26 Law \& Pol’y Int'l Bus. 1169 at 1182-83.

Gregory M. Starner, “Taking a Constitutional Look: NAFTA Chapter 11 as an Extension of Member States’ Constitutional Protection of Property” (2002) 33 Law \& Pol'y Int’l Bus. 405 at 414-17.

Gloria L. Sandrino, "The Nafta Investment Chapter and Foreign Direct Investment in Mexico: A Third World Perspective” (1994) 27 Vand. J. Transnat’1 L. 259 at 288.

Patrick Del Duca, “The Rule of Law: Mexico’s Approach to Expropriation Disputes in the Face of Investment Globalization” (2003) 51 UCLA L. Rev. 35 at 73-76 [footnotes omitted]; ibid. at 283-308. Sandrino, ibid.

C. Kemm Yates \& Bernard J. Roth, "The Effect of the North American Free Trade Agreement on the Oil and Gas Laws of Canada” in James R. Holbein \& Donald J. Musch, eds., North American Free Trade Agreements (New York: Oceana, 1995).

See supra note 16, Annex 602.3 (regarding energy trade), Annex 300-A (regarding investment). This reservation has come at a very high cost to Mexico. In stark contrast to Alberta, Mexico has been unable to raise capital to develop its resources in the deep waters of the Gulf of Mexico. Without this capital, Mexico’s production has been experiencing declines. Mexico has been looking at ways to get around these barriers to private capital. See Catherine Bremer \& Alistair Bell, "Mexico Pemex Fears 'Crippled' Oil Reform” Reuters UK (4 April 2008), online: Reuters UK <http://uk.reuters.com/article/elections News/idUKN0327930720080404>. 
NAFTA. ${ }^{25}$ As a result, neither the sovereignty of Parliament nor the Canadian legislatures provides any defence to the NAFTA investor claims concerning Canadian energy resources. ${ }^{26}$ Ironically, although there is no constitutional protection for property rights within Canada, the NAFTA provides U.S. and Mexican investors in Canada with quasi-constitutional property rights protection. ${ }^{27}$ The issue this article will address is whether the protection afforded by the NAFTA can withstand the voices calling for change to Alberta's oil sands royalty regime. Specifically, this article will address whether the changes Alberta is proposing to oil sands royalties constitute compensable expropriation pursuant to art. 1110 of the NAFTA.

\section{OIL SANDS INVESTMENT}

The NAFTA protects “investments.” In order to undertake a NAFTA analysis, it is helpful to describe a generic oil sands investment cycle. A NAFTA investor who is new to Alberta is likely to incur significant expenses to obtain professional advice regarding the laws and the regulatory regime applicable to investing in Alberta's oil sands, as well as information regarding prospective resources that may be available for exploitation. This generally requires the acquisition of significant amounts of information from both public and confidential sources regarding the oil sands resource potential of various tracts of land. Alberta law allows new geological and geophysical work to be undertaken on available Crown lands. This too can be a costly undertaking. Once an investor has acquired sufficient information to confirm that certain Crown lands are prospective, the investor can apply to the Alberta Department of Energy to have lands posted for bidding at a public auction. Posted lands are awarded to the highest bidder. Acquiring oil sands tenure over Crown lands constitutes a significant investment. For example, in the period leading up to the royalty review, a block of oil sands parcel was acquired for just under a half billion dollars. ${ }^{28}$ In deciding how much to bid for a parcel, an investor will closely evaluate the characteristics of the oil sands resource in the lands, potential development costs to obtain production, and projections of oil prices, Crown royalties, and taxes.

25 The few reservations maintained by Canada included the preservation of domestic content requirements pursuant to Canada's east coast offshore legislation governing oil and gas development off of Newfoundland and Nova Scotia. The extent of this reservation was challenged in Mobil Investments Canada v. Canada, ICSID Case No. ARB(AF)/07/4 (the request was declined on 10 December 2008). There is a domestic constitutional issue in Canada as to whether the NAFTA can bind Canadian provinces because of Canada's constitutional division of powers. This should not, however, affect American or Mexican investors. Their claim is against the Government of Canada which would be liable to them directly for damages and costs: see Macdonald, supra note 15 at 285. The domestic issue is whether the Government of Canada could somehow recover the award to the investor from the province of Alberta. In the context of the Mexican Constitution, the one NAFTA expropriation award to date apparently could not be recovered by setting off against transfer payments from the Mexican state that triggered the award: see Jesse Williams, "Regulating Multinational Polluters in a Post-NAFTA Trade Regime: The Lessons of Metalclad v. Mexico and the Case for a 'Takings' Standard” (2003) 8 UCLA J. Int'l L. \& Foreign Aff. 473 at 484.

27 For a discussion of how the NAFTA effectively creates constitutional protection of property rights, see David Schneiderman, “NAFTA’s Takings Rule: American Constitutionalism Comes to Canada” (1996) 46 U.T.L.J. 499.

28 “Alberta Crown Bonuses Surpass \$1 Billion Already” Nickle’s Daily Oil Bulletin (9 February 2006). 
Once a Crown oil sands lease is acquired, the investor will likely undertake a further assessment of the oil sands resource on the property acquired in order to create a development scheme to support the necessary regulatory approvals that will be required to produce the oil sands. Securing these approvals is a major undertaking involving the expenditure of tens of millions of dollars for significant oil sands projects.

After regulatory approvals are secured, investors generally undertake detailed engineering work to develop cost estimates to undertake projects. These cost estimates are needed to obtain further financing and/or corporate board approval to undertake the projects. At the point of committing to actual project execution, investment commitments go beyond the millions that have been spent on development costs and into the billions associated with project execution costs. These oil sands investments are incurred over a period of many years before a large project will start operations and the investor can commence recovering its costs. Cost recovery and project return is then earned over the life of a project, which can be 40 years or more.

At any point during the oil sands investment cycle of any given project, oil sands investment will change hands through a very active mergers-and-acquisitions market. The purpose of this activity is often to provide financing and it frequently involves the commitment of foreign capital. Merger and acquisition activity in Alberta's oil sands reached a record $\$ 18.6$ billion in $2007 .{ }^{29}$

The technological, environmental, and commercial risks associated with the oil sands are as massive as the resource itself. It would not likely be feasible for Alberta to develop the oil sands with public capital. Alberta oil sands resources have been developed by accessing foreign capital, much of it from American oil companies. Alberta's first commercial oil sands project was undertaken by an American oil company. ${ }^{30}$ This oil sands investment was subsequently sold, and is now in the hands of Suncor, which is a Canadian company. Canada's second oil sands project, which is currently the largest, was a joint venture undertaking between American and Canadian companies, as well as Canadian governments. This joint venture, called Syncrude, is still constituted through the investments of Canadian and American oil and gas enterprises, as well as other foreign oil companies. The government working interests in Syncrude have all been liquidated. Currently, most major American oil producers and many other foreign controlled entities have significant investments in Alberta's oil sands.

\section{OIL SANDS TENURE}

A current form of oil sands lease contains the following grant and reservation provisions:

WHEREAS Her Majesty is the owner of the minerals in respect of which rights are granted under this Lease;

$29 \quad$ Pat Roche, “Oilsands Deals Seen Slowing After Rising To \$18.6 Billion From \$2 Billion In Three Years” Nickle's Daily Oil Bulletin (14 March 2008).

Great Canadian Oil Sands Limited was a subsidiary of Sun Oil Company of Pennsylvania. It obtained approval and commenced construction of a 45,000 barrels per day project in 1964: “The Oil Sands Story (1960s, 1970s \& 1980s),” online: Suncor Energy <http://www.suncor.com/popup.aspx?cid=332>. 
THEREFORE, subject to the terms and conditions contained in this Lease, Her Majesty grants to the Lessee, insofar as Her Majesty has the right to grant the same, the exclusive right to drill for, win, work and recover the Leased Substances within the Location, together with the right to remove from the Location any Leased Substances recovered, for the term of fifteen (15) years computed from the Term Commencement Date and, subject to the Mines and Minerals Act, for so long after the expiration of that term as this Lease is permitted to continue under the Mines and Minerals Act;

RESERVING AND PAYING to Her Majesty,

(a) in respect of each year during which this Lease remains in effect, a clear yearly rental computed at the rate prescribed by, and payable in accordance with, the Mines and Minerals Act, and

(b) the royalty on all Leased Substances recovered pursuant to this Lease, that is now or may hereafter from time to time be prescribed by, and that is payable in accordance with, the Mines and Minerals Act, such royalty to be calculated free of any deductions except those that are permitted under the Mines and Minerals Act.

1(1) In this Lease, a reference to the Mines and Minerals Act or to any other Act of the Legislature of Alberta referred to in section 2(2)(b) of this Lease shall be construed as a reference to

(a) that Act, as amended from time to time,

(b) any replacement of all or part of that Act from time to time enacted by the Legislature, as amended from time to time, and

(c) any regulations, orders, directives or other subordinate legislation from time to time made under any enactment referred to in clause (a) or (b), as amended from time to time. ${ }^{31}$

The Mines and Minerals Act ${ }^{32}$ provided for the negotiation of project-specific royalties. Historically, oil sands investors would enter into Crown agreements with the province of Alberta to provide fiscal terms that would be applicable to a proposed oil sands project. Each time a developer wanted to change or expand its approved project, it would have to approach the province of Alberta to renegotiate the applicable fiscal terms. Any new projects would likewise require individual Crown agreements. This provided the Crown considerable flexibility, not only with respect to new projects, but also with respect to any existing projects that would inevitably require some form of modification or expansion triggering renegotiation. This flexibility on the part of the Crown came with corresponding uncertainty for investors, which in turn inhibited oil sands investment and development. In 1995, a joint industry-government task force (the National Task Force on Oil Sands Strategy) recommended that Alberta adopt a generic royalty regime. ${ }^{33}$ The Alberta Department of Energy describes the recommendation as follows:

31 See e.g. Alberta Energy, Oil Sands Lease No. 7406080084, online: SEC Info <http://www.secinfo. com/d1Ze2u.u2T7.8.htm>.

32 R.S.A. 2000, c. M-17 [MMA].

33 Alberta Chamber of Resources National Task Force on Oil Sands Strategies, The Oil Sands: A New Energy Vision for Canada (Edmonton: Alberta Chamber of Resources, 1995). 
The task force believed that a generic approach to oil sands royalty would place all new projects on a level playing field. Standard royalty terms would create fiscal certainty and stability, and encourage oil sands investment.

The Government of Alberta accepted that recommendation of the task force and began work to develop legislation and policy to support a generic oil sands royalty regime. ${ }^{34}$

The Alberta government went on to amend the $M M A$ to prescribe a royalty of 1 percent pre-payout and 25 percent post-payout. ${ }^{35}$ Existing Crown agreements with Syncrude and Suncor continued in place. The fiscal terms specified in Syncrude and Suncor's Crown agreements will run until $2016 .^{36}$

It should be emphasized that the intention of the generic oil sands royalty regime was to provide greater investment certainty than was thought to be available through Crown agreements. The problem with Crown agreements that inhibited existing oil sands projects, as well as new ones, was that planning was subject initially to their negotiation and then to getting repeated amendments as projects expanded and evolved. The certainty associated with the implementation of the new 1997 generic oil sands royalty regime was highlighted by the fact that the royalty rates were incorporated directly into the legislation, rather than being left to prescription by regulation, as is the case with conventional oil and gas royalties.

By any measure, Alberta’s generic oil sands royalty regime delivered precisely what the province of Alberta was seeking: substantial investment and expanded oil sands production. In 1997, oil sands production stood at 512,000 barrels per day (bbls/d). ${ }^{37}$ By the end of 2007, that figure had grown to 1.2 million bbls/d. ${ }^{38}$ This increase in production has been obtained through cumulative capital investment of $\$ 88.4$ billion between 1997 and $2007 .{ }^{39}$ A further $\$ 110$ billion in capital has been committed to the execution of approved oil sands projects, which will take oil sands production to 4.4 million bbls/d by $2015 .{ }^{40}$

Alberta Department of Energy, Alberta Oil Sands Royalty Guidelines: Principles and Procedures (30 November 2006), online: Alberta Energy <http://www.energy.gov.ab.ca/OilSands/pdfs/GDE_osr. pdf> at para. 1.1.1 [Royalty Guidelines].

35 See supra note 32, ss. 90(2)-90(3). Pursuant to s. 34(3) of the MMA, supra note 32, this royalty is taken in-kind, subject to the regulations. Currently, the Oil Sands Royalty Regulation, 1997, Alta. Reg. 185/1997, s. 25, provides that oil sands project owners must sell the Crown's royalty share as agents on behalf of the Crown and remit the proceeds.

36 See Richard Macedo, “Alberta’s Expected Surplus Shrinks, Deal Reached With Syncrude” Nickle's Daily Oil Bulletin (19 November 2008); "Suncor To Pay Higher Royalties Starting In 2010" Nickle's Daily Oil Bulletin (29 January 2008).

37 This includes synthetic crude and crude bitumen: see Canadian Association of Petroleum Producers (CAPP), Technical Report: Statistical Handbook for Canada's Upstream Oil Industry (March 2009), online: CAPP <http://www.capp.ca/GetDoc.aspx?DocID=146286>, Table 3.2.a [Technical Report]. The conversion factor used by the CAPP in this Technical Report listed on the "Metric Conversion Factors" page is one Canadian barrel of oil, condesate or pentanes $=0.15891$ cubic metres of oil, condesate or pentanes at $60^{\circ} \mathrm{F}$ or $15^{\circ} \mathrm{C}$.

38 Canadian Association of Petroleum Producers (Personal Communications with Brian Woods).

39 Technical Report, supra note 37, Table 4.16b; ibid.

40 National Energy Board, Canada's Oil Sands: Opportunities and Challenges to 2015: An Update (Calgary: National Energy Board, 2006) at 12. 


\section{OIL SANDS Royalty ReVIEW}

Alberta's royalty regime initially withstood some calls for change. While other jurisdictions were taking measures to capture further benefits from increasing world oil prices, the Alberta government, led by then-Premier Ralph Klein, who had worked with industry in developing the generic oil sands regime, stood firmly against making any changes. The Alberta government indicated that it had undertaken an internal review and Alberta's Minister of Energy confirmed that there was no reason to increase royalties.

Things changed in 2006. Premier Klein, who had served since 1992, retired and a leadership race followed. The candidate who eventually prevailed, Ed Stelmach, made a promise during his campaign that, if he were chosen as leader, a public review of Alberta's oil and gas royalties would be undertaken. One of the first things the new Premier did after taking office was to constitute the Alberta Royalty Review Panel. Although the Review Panel adopted a public process, it was not a public inquiry. The Review Panel was neither judicial nor quasi-judicial in nature. Rather, it was political. The Review Panel travelled the province and conducted town hall meetings, where it heard submissions from members of the public who cared to address it.

In September 2007, the Review Panel delivered its report to Alberta’s Minister of Finance. The report title, Our Fair Share, was aptly chosen given the recommendations it contained. The Review Panel recommended significant increases to oil sands royalties and the introduction of a new oil sands severance tax. The 1 percent pre-payout royalty was maintained at its current rate. However, it became an additive royalty after post-payout royalties became payable. The post-payout royalty was to be increased from 25 to 33 percent. The recommended severance tax was a gross revenue tax tied to oil prices. The tax ranged from a low of 1 percent at $\$ 40$ a barrel to a high of 9 percent at $\$ 120$ a barrel.

The Review Panel Report commenced its discussion of oil sands by addressing the 1997 generic oil sands regime as follows:

The royalty and tax regime for oil sands projects is a major component of the government's side of the "bargain" with developers and producers to bring bitumen to market. This chapter will propose changes to royalties and taxes, and it will be argued against these changes that they are "breaking the bargain". The bargain was "broken" once before, in the late nineteen nineties. The oil sands sector was new, and undercapitalized. Energy prices were low and the sector was unsure if it had a future. The Governments of Alberta and Canada agreed to change the royalties and taxes then in place to a far less onerous scheme, so that the industry could survive and develop. Industry got the breaks it needed and asked for. Oil sands have since emerged as the dominant factor in Canada's energy future. The breaks given ten years ago are still in place. Just as rebalancing was needed a decade ago, this chapter demonstrates that rebalancing is needed again now. $^{41}$

There is an internal inconsistency in the Review Panel's reasoning. On one hand, it is suggesting that the bargain was broken in the late 1990s (presumably on the implementation of the generic oil sands regime in 1997), but it goes on to state that "Alberta ... agreed to 
change the royalties.” ${ }^{42}$ Adoption of the 1997 generic oil sands royalty regime did not constitute the breaking of any bargain. Industry approached governments with a proposal pursuant to which Alberta would be able to attract oil sands investment and develop its resources. The Government of Alberta accepted the proposal. As referenced above, the industry invested heavily. The Review Panel Report acknowledges that the existing oil sands royalty regime had already attracted substantial investment. However, in its discussion of "grandfathering," it treats this as a practical problem, rather than a legal one. It states:

The concept of grandfathering has general application for every single recommendation of this Report. However, its impact is greatest for the oil sands, so it is discussed in detail here.

Simply stated, "grandfathering” exempts existing projects from new rules. The concept has potentially broad implication for any changes in the royalty system. If all pre-existing leases and permits are grandfathered under any new rules, then new rules would only apply to new leases and projects. Almost nothing would change. Since the bulk of Alberta's energy leases are already let and the producers now in operation will dominate the market for years to come, there would be very little scope to improve the system. A broad concept of "grandfathering" would preclude the changes of benefit to Albertans, as well as those to benefit to industry. ${ }^{43}$

The Review Panel concludes its discussion of grandfathering by stating:

[M]any of the world's producers have raised royalty rates in recent years with little impact on their investment, the extreme case of Venezuela's 2007 changes being an exception. As well, there has been a general trend toward more nationalization under state-owned energy companies or direct state participation in energy exploitation, particularly in large and complex projects. Newfoundland's recent $5 \%$ - $10 \%$ buy-in deals are a very current Canadian example.

While it may not be 'best practice' for a government to change the rules after projects have begun, it is definitely not 'best practice' for the Government of Alberta to accept something less than a 'fair share', simply because the rules currently in place might have represented a fair share a decade ago under very different conditions. Two valid principles come into conflict because of changes in world energy markets. ${ }^{44}$

The Review Panel's conclusion on grandfathering is extremely difficult to understand in light of its earlier discussion in respect of the Syncrude- and Suncor-Crown agreements. In addressing these agreements, the Review Panel states:

Note as well that, for these two developers, the provisions of the current royalty regime (including the rates at which both base and net revenue royalties are to be paid) are enshrined in their Crown Agreements, until the Crown Agreements lapse at the end of 2015. Should proposed changes in the royalty rates be applied to these developers, they might have legal recourse. The financial implications for the developers and for Alberta are significant. In principle, a consistent royalty regime would be preferred, but in practice the cost

$42 \quad$ Ibid. at 74.

$43 \quad$ Ibid. at 84 [emphasis added].

44 Ibid. [emphasis in original]. 
of changing these agreements must be assessed against the benefits of doing so. That assessment is beyond the scope of the Panel's work. ${ }^{45}$

As discussed above, the reason industry and government went to a legislatively prescribed generic oil sands royalty regime was to increase the investment certainty that could be achieved for industry relative to that available under Crown agreements. The Review Panel suggests there might be legal recourse under Crown agreements. It seems to assume that there would not be legal recourse for those who relied on the generic oil sands regime, which was intended to provide industry with greater certainty regarding the security of investment.

Finally, reference should also be made to "The Chairman's Afterword" to the Review Panel Report. The point of this post-script was to acknowledge that, throughout the royalty review, the public had repeatedly expressed its concern for protection of the environment. These public concerns were acknowledged. However, the Chairman remarks that the Review Panel had concluded that the royalty regime was "not the vehicle to accommodate environmental protection and mitigation." 46 The Chairman suggests that it was the Review Panel's hope that its work would create an opening for the public and the government to explore opportunities to accommodate growing public concerns regarding the environment. ${ }^{47}$ The reason the Chairman's Afterword is important is because it acknowledges that increased royalties were all about, and only about, money. They had nothing to do with the environment or advancing the cause of environmental regulation.

A vigorous debate followed the release of the Review Panel Report, but it was not about the environment. Albertans had been told that they were not receiving their fair share, and not surprisingly, they were demanding increased royalties from the government. The reaction of industry was initially to express surprise and then to challenge the facts and assumptions upon which the Review Panel based its recommendations. Highlighting the fact that the Review Panel was not a judicial or quasi-judicial tribunal, it used the media to defend its report and recommendations. In response to questions as to whether higher royalties could make some oil sands plays "unfeasible," the Chairman of the Review Panel is reported to have said that companies could cut their costs or "leave [the oil sands] in the damn ground."48

The Government of Alberta responded to the Review Panel Report by releasing The New Royalty Framework in October 2007..$^{49}$ Although it did not adopt all of the Review Panel's recommendations, it decided to increase oil sands royalties substantially. The Government

45 Ibid. at 82. The Review Panel's understanding of grandfathering as it relates to oil sands royalties is considerably different than articulated by the Alberta Energy's Royalty Guidelines, supra note 34. At para. 5.8 of the Royalty Guidelines, the Alberta Department of Energy explains that the reason there can be no grandfathering is because of parliamentary supremacy. Under parliamentary supremacy, there are no limits to which the legislature can go in either amending or cancelling contracts, as well as changing legislation; but see Monahan, supra note 4, who suggests that there may be limits to how far legislation can go in affecting contracts.

Our Fair Share, ibid. at 103.

Ibid. at 104.

Jason Markusoff, “Industry argument 'distorts picture’; Review panel says its conclusions based on sound data provided by oilpatch” Edmonton Journal (27 September 2007) A3.

Alberta Department of Energy, The New Royalty Framework (25 October 2007), online: Alberta Energy <http://www.energy.gov.ab.ca/Org/Publications/royalty_Oct25.pdf> [New Royalty Framework]. 
rejected the idea of an oil sands severance tax. Instead, the Government said it would increase the pre-payout royalty of 1 percent to a maximum of 9 percent and the post-payout royalty would be raised from 25 percent to a maximum of 40 percent. Royalty rates would start to rise at crude oil prices of $\$ 55$ a barrel and reach their maximum levels at $\$ 120$ a barrel. ${ }^{50}$ The Government said that it would not grandfather any oil sands projects from these royalty changes, including the Syncrude and Suncor projects. ${ }^{51}$

Suncor has reported reaching an agreement with the Government of Alberta to increase its royalties by 20 percent prior to the expiry of its Crown agreement in $2016 .{ }^{52}$ Imperial Oil has reported that the Syncrude joint venture would be willing to accept the same arrangement as the Government made with Suncor, subject to being compensated for the loss of value associated with the royalty change. ${ }^{53}$

The royalty review debate and the proposed royalty changes appear to have had a noticeable impact on Crown land sales. Total oil sands Crown bonuses went from a record of $\$ 1.96$ billion in 2006 to $\$ 649.7$ million in $2007 .^{54}$ This downward trend established in 2007 continued in 2008. ${ }^{55}$

\section{Canadian Law}

\section{A. Legal Nature of Crown OIL SANDS LeASE AND Reserved Royalty}

The international customary law of expropriation and the NAFTA distinguish between direct and indirect expropriation. It has been persuasively argued that, when assessing what constitutes expropriation under international law, it is essential to examine the domestic law which constitutes the rights affected by the alleged expropriatory measures. ${ }^{56}$ This requires a characterization of the interest created through a Crown oil sands lease and the reserved royalty.

With oil prices approaching these levels, it should be noted that the Alberta government has not been entirely clear on how frequently it might adjust royalties. The Minister of Energy first indicated that the soonest this may occur would be 10 years, but later suggested it might be five years. See "Oil Sands Negotiations - Messy" Doig's Digest 26:4 (April 2008) at 8.

New Royalty Framework, supra note 49 at 3.

Ibid. at 10, 13.

Ibid.

Alberta Department of Energy, "Oil Sands - Statistics (Public Offerings) — Calendar Year Totals," online: Alberta Energy <http://www.energy.gov.ab.ca/OilSands/1236.asp>.

Ibid. For the first quarter of 2008, Alberta bonus revenue stood at \$75.7 million, down from \$223.24 million in 2007, putting Alberta behind British Columbia and almost equal to Saskatchewan. Both of these provinces chose not to follow Alberta's lead in changing royalties: see "Producer Land Spending Moves To B.C. And Saskatchewan” Nickle's Daily Oil Bulletin (2 April 2008). The second quarter of 2008 has seen Alberta's position further deteriorate, with Saskatchewan now in the bonus revenue lead after taking in over a quarter of a billion dollars at its first second quarter land sale: see "WeyburnEstevan Area Parcels Help Saskatchewan Take In \$265.66 Million” Nickle’s Daily Oil Bulletin (11 April 2008).

56 Céline Lévesque, "Distinguishing Expropriation and Regulation Under NAFTA Chapter 11: Making Explicit the Link to Property" in Kevin C. Kennedy, ed., The First Decade of NAFTA: The Future of Free Trade in North America (Ardsley, N.Y.: Transnational, 2004) 293. 
It is settled law that a Crown oil sands lease in Alberta creates an interest in land known at common law as a profit à prendre. ${ }^{57}$ It has also been determined that the rights established through a Crown oil sands lease are no different than the rights established pursuant to an oil and gas lease created out of a private freehold estate. ${ }^{58}$

It is now settled law that an oil royalty can constitute an interest in land.$^{59}$ The concern that the courts originally had with the characterization of a royalty as an interest in land was that it created the potential for a proliferation of new types of interests in land. Most of the decisions holding that a royalty was not an interest in land were overriding royalty cases where the interest was created by the lessee or someone with a working interest in a lease. This is obviously not a concern with respect to the Crown's royalty. The Crown's royalty is created by way of reservation out of the original grant. The lessee is required to deliver up the royalty in kind at the first point of measurement, unless otherwise directed by the Crown. ${ }^{60}$

Once the nature of the interest held by the Crown lessee and the Crown has been characterized, it is important to characterize the nature of the measures being undertaken to increase royalties. The Crown, through the legislature, will have to amend the MMA to increase the amount of the royalty reserved under oil sands leases. When determining whether the measure is considered to be an act of direct, as opposed to indirect expropriation, it may be necessary to characterize the nature of the measure. In particular, it is important to understand whether the measure is regulatory in nature such that the intent is to regulate or legislate in respect of matters of public interest such as health, safety, or the environment. This is certainly not the complete list of matters that can be the subject of regulatory measures. However, in the case of the increase in royalties arising out of the Review Panel's Our Fair Share report, it is abundantly clear that increasing royalties is all about money and nothing else. Notably, the New Royalty Framework document, which announced the Alberta government's design to increase royalties, does not suggest that the royalty increases were intended to be regulatory measures.

The Supreme Court of Canada addressed this issue in Natural Gas Tax. ${ }^{61}$ In that case, the Government of Canada argued that the pith and substance of the federal tax being placed on export sales of gas by Alberta was regulatory in nature and not taxation. The majority of the Court stated that "Bill C-57 contains no language to indicate that the tax is imposed as a regulatory device.”62 In confirming this interpretation, the Court went on to review the NEP 1980 which was issued shortly before Bill C-57 was enacted. The Court held that on a cursory reading of that document, it was clear that the federal government could not ground its measures taken against Alberta's natural gas as being regulatory in nature. ${ }^{63}$ The Court recognized that a measure under Canadian constitutional law could have a "double aspect,"

Alberta Energy v. Goodwell Petroleum Corp. Ltd., 2003 ABCA 277, 339 A.R. 201 at para. 63 [Goodwell].

Ibid. at para. 62.

Bank of Montreal v. Dynex Petroleum Ltd., 2002 SCC 7, [2002] 1 S.C.R. 146 at para. 21.

MMA, supra note 32, ss. 34(1)-(3).

Supra note 6.

Ibid. at 1073.

Ibid. at 1077-78. 
one aspect being taxation, but another being regulatory. ${ }^{64}$ In other words, a regulatory measure could be implemented through taxation. Again, this argument failed because there was nothing regulatory about the NEP as it purported to apply to export sales of natural gas belonging to the Alberta Crown.

Notwithstanding that taxation can constitute expropriation pursuant to both customary international law and the NAFTA, it is still important for the purposes of the NAFTA to determine whether the measures proposed by Alberta to extract higher Crown oil sands royalties constitute taxation. There are procedural consequences associated with expropriation claims brought under the NAFTA if they relate to taxation measures. ${ }^{65}$

The Supreme Court of Canada addressed the distinction between a true "royalty" and taxation in CIGOL. In that case, the Saskatchewan government purported to impose a royalty surcharge under the provisions of its form of Crown lease. The royalty clause of the Saskatchewan Crown lease stated as follows:

And also rendering and paying therefor unto the Lessor any royalties at such rates and in such manner and at such times as are from time to time prescribed by the Order of the Lieutenant Governor in Council: such rents and royalties to be free and clear of and from all rates, taxes and assessments and from all manner of deduction whatsoever. ${ }^{66}$

Justice Martland, for the majority, held that the royalty surcharge was a tax, stating:

In my opinion the word "royalty" was used in the leases in its customary sense as meaning a share of the production obtained by the lessee. My view is reinforced by the use of the word "rate" which contemplates the determination of the proportions of production allocated to the lessor.

In my opinion the royalty surcharge made applicable to these Crown leases was not a royalty for which provision was made in the lease agreement. It was imposed as a levy upon the share of production to which, under the lease, the lessee was entitled, and was a tax upon production. ${ }^{67}$

The Alberta government's increased royalty would still appear to be a true royalty and not a tax, pursuant to this analysis. Although it is not possible to express an opinion until the exact wording of the amending legislation is brought forward, it can be anticipated that the Alberta government will still apply a rate to the royalty calculation and provide for royalty barrels measured being taken in kind. ${ }^{68}$ The characterization of Alberta's increased royalty as a true royalty or as a tax is also assisted by the Supreme Court of Canada's decision in

$64 \quad$ Ibid. at 1074.

65 See Part VII.C, below.

$66 \quad$ CIGOL, supra note 3 at 561.

67 Ibid. at 561-62. In dissent, Dickson J. also agreed with this conclusion. His dissent was based on whether the tax was indirect.

68 On this last point, the Alberta government has suggested that it may rely on taking its oil sands royalty in kind as a means of encouraging the construction of bitumen upgraders in the province: New Royalty Framework, supra note 49 at 10. 
Natural Gas Tax. In addition to arguing that the tax was a regulatory measure, the federal government had an alternative argument that the tax was in fact expropriation and argued that it was entitled to expropriate provincial Crown property pursuant to previous Supreme Court of Canada decisions. The Supreme Court of Canada in that case rejected the expropriation argument and in doing so stated:

\footnotetext{
Expropriation by either level of government without legislative root in the Constitution is not a legal right and cannot take place legally. What we are talking about here is not expropriation of gas but taxation of gas, or, as the federal government submits, taxation of the movement of gas. Title to the gas at no time vests in the Government of Canada or its designate. Title transfers from the province to its customer. The transaction is purported to be subjected to tax federally. ${ }^{69}$
}

In this respect, Alberta's increased royalty bears a subtle, but important, distinction from the federal government's NEP excise tax on Alberta's natural gas. Although both were motivated by a desire for a fair share of the value of the resource, there is little doubt that the mechanism used by Alberta accomplishes this by enhancing its pre-existing proprietary interest. Unlike the Government of Canada, Alberta will own the increased royalty barrels it takes from Crown lessees. A further distinction is that the increased Alberta royalty affects the underlying interest of the Crown lessee. By increasing the royalty, Alberta will derogate from the profit that constitutes the Crown lessee's interest in land. Correspondingly, the Alberta Crown's royalty interest, which is also an interest in land, will be enhanced by an amount equal to this derogation. If what the province of Alberta is doing can be characterized as "expropriation," it is not only expropriation of barrels of severed oil sands, but also the expropriation of a partial interest in the lessee's interest in land.

\section{B. LAW OF EXPROPRIATION}

The Canadian law of expropriation is primarily defined by the common law, though most provinces have enacted expropriation legislation governing the expropriation process. The process covers both how the taking can occur and the compensation, if any, that is to be paid.

In Alberta, there is the Expropriation Act. ${ }^{70}$ Section 2 of the Expropriation Act states:

This Act applies to any expropriation authorized by the law of Alberta and prevails over any contrary provisions that may be found in the law, except the statutes or parts or statutes enumerated in the Schedule.

(2) This Act binds the Crown. ${ }^{71}$

The terms “expropriation,” "land,” and “owner” are defined in ss. 1(g), (h), and (k):

(g) "expropriation" means the taking of land without the consent of the owner by an expropriating authority in the exercise of its statutory powers; 
(h) "land" means land as defined in the authorizing Act and if not so defined, means any estate or interest in land;

(v) in the case of Crown land, a person shown on the records of the department administering the land as having an estate or interest in the land. ${ }^{72}$

The Expropriation Act includes Crown leases. This is apparent from the definition of "owner." It is also apparent from the exclusion provisions of the Schedule referenced in s. 2(1). These exclusion provisions include cancellation or failure to renew Crown leases in certain circumstances. ${ }^{73}$ It is also apparent from the legislation that measures, which are far less intrusive than cancellation or non-renewal, are considered to be expropriation. The Schedule excludes the implementation of schemes to maximize the recovery of oil sands pursuant to s. 18 of the Oil Sands Conservation Act. ${ }^{74}$ The conservation schemes under s. 18 of the OSCA are essentially schemes to prevent sterilization of oil sands at lease boundaries where leases are owned by two different operators. In order to promote efficiency and prevent sterilization of oil sands ore, s. 18 allows pockets of ore of one lessee to be mined by another along the edges of a common lease boundary. The Crown oil sands leases themselves are not affected. There is, arguably, a minor and temporary derogation from the exclusivity of the grant. It is implicit in the Expropriation Act that the legislature considers exceptions to this exclusivity to be expropriation. However, the Schedule excludes such measures from the Expropriation Act. There are no other exclusions in the Expropriation Act that permit the legislature, the government, the Energy Resources Conservation Board, or any other expropriating authority from affecting rights or interests of a Crown oil sands lessee without payment of compensation. In particular, there is nothing in the Expropriation Act that excludes powers in the MMA to establish or change royalties from the legislative requirement to pay compensation.

In Canada, the substantive law of expropriation continues to be greatly influenced by the common law. The common law's protection against expropriation is broader than that afforded by the Expropriation Act. This is apparent from a review of the case law. The leading case on expropriation continues to be the House of Lords decision in AttorneyGeneral v. De Keyser's Royal Hotel, Limited..$^{75}$ De Keyser's Royal Hotel was a hotel in London. During World War I, the hotel was commandeered by the British military to house the administrative staff of the Royal Flying Corps. The Crown took the position that the hotel was required for defence of the realm. At the time of taking up the hotel, the Crown relied

See ibid., Schedule, para. 6, which excludes cancellations and refusals to renew Crown leases pursuant to s. 8(1)(c) of the MMA, supra note 32.

74 R.S.A. 2000, c. O-7 [OSCA]. This exclusion is stated in para. 7 of the Schedule to the Expropriation Act, supra note 70 .

[1920] A.C. 508 (H.L.) [De Keyser]. 
on the Defence of the Realm Consolidation Act, $1914,{ }^{76}$ which consolidated various war measures statutes going back to 1842. All of the statutes prescribed an expropriation procedure and provided for compensation. The consolidation legislation, however, provided that expropriation could be undertaken pursuant to the earlier legislation by regulation and without the restrictions contained in the earlier legislation. The Crown relied on a regulation enacted under the consolidated legislation. The Crown asserted that one of the restrictions that it was exempted from was the requirement to pay compensation. In addition to this position, at the House of Lords, the Crown argued that it also held a residual power pursuant to its prerogative to expropriate property in defence of the realm without compensation.

The hotel owner sued for compensation associated with the temporary occupation of the hotel. The House of Lords held that where Parliament provided for expropriation by statute, there was no room left for an inconsistent exercise of a royal prerogative. ${ }^{77}$ As to whether the consolidating legislation and its regulations excluded the right of compensation, Lord Atkinson stated:

\begin{abstract}
The words of sub-s. 2, moreover, are "restrictions on the acquisition or use of land.” When those restrictions are examined it is, in my mind, clear that the legal obligation to pay for the land or its use, temporarily or permanently acquired, is not a restriction upon the acquisition of either, or a condition precedent to its acquisition. There is nothing in the statute to suggest that the liability to pay is to be affected or taken away by the Regulations which may be issued, and if the Regulations purported to do that I doubt if they would not, having regard to the wording of sub-s. 2, be ultra vires. Neither the public safety nor the defence of the realm requires that the Crown should be relieved of a legal liability to pay for the property it takes from one of its subjects. The recognized rule for the construction of statutes is that, unless the words of the statute clearly so demand, a statute is not to be construed so as to take away the property of a subject without compensation. $^{78}$
\end{abstract}

The issue of the extent of the royal prerogative to expropriate was subsequently determined by the House of Lords as a result of the events of World War II. In Burmah Oil Co. Ltd. v. Lord Advocate, ${ }^{79}$ the plaintiff sought compensation from the Crown as a result of the destruction of its oil fields near Rangoon. In the days leading up to the Japanese advance on Burma, plans were made to evacuate Burma and retreat to the defence of India. The day before the Japanese occupied Rangoon, British forces destroyed the plaintiff's oil fields so as to deny the Japanese army their benefit. The House of Lords held that compensation was payable in all cases except for damage done in the heat of battle. Lord Pearce stated:

I would define the line as excluding damage done in the battle or for the necessities of the battle. If an evacuating army destroys as it goes, I would exclude from compensation any damage which it does for the purposes of its survival, for example, by destruction of ammunition which will be turned against it by the enemy, or petrol which will be used by the enemy to pursue it, or food which will sustain the enemy during their attacks upon it. But more general damage done with a view to weakening or depriving the enemy in the

(U.K.), 5 Geo. V, c.8.

De Keyser, supra note 75 at 567.

Ibid. at 542 [emphasis added]. Lord Parmoor stated the same common law rule as follows: “[U]nless no other interpretation is possible, justice requires that statutes should not be construed to enable the land of a particular individual to be confiscated without payment” (at 576).

[1965] A.C. 75 (H.L). 
not immediate future, especially when the scene of battle will have moved elsewhere, comes in the category of deliberate destruction done outside the battle. The destruction of oil wells, like various forms of economic warfare, is quite outside the battle damage, and the fact that the battle may have dictated the date of the destruction is irrelevant. $^{80}$

The House of Lords declined to follow the U.S. Supreme Court, which had denied compensation in similar circumstances. Lord Pearce stated:

[I]n the United States v. Caltex (Philippines) Inc. the Supreme Court, reversing the Court of Claims, refused compensation under the Fifth Amendment in respect of terminal facilities, such as wharves, rails, pumps, storage tanks and other property of oil companies destroyed in Manila at the time of the Japanese attack on Pearl Harbour to prevent its imminent capture and use by the enemy.

If I am right in thinking that a great part at least of the ratio of the majority was that the property was destroyed, not appropriated for subsequent use, I respectfully accept that distinction for the purposes of the Fifth Amendment with which the learned Chief Justice was dealing; but for the purposes of English common law I prefer the reasoning of the minority. ${ }^{81}$

The leading Canadian case on expropriation is the Supreme Court of Canada's decision in Manitoba Fisheries Ltd. v. Canada ${ }^{82}$ Federal legislation was passed to implement a new freshwater fish marketing scheme through a Manitoba Crown corporation. The legislation delegated to Manitoba the discretion to pay compensation to parties affected by the new marketing scheme. Manitoba Fisheries Ltd. (Manitoba Fisheries) had been purchasing and exporting freshwater fish from Manitoba for 43 years. Manitoba Fisheries sued the federal government for compensation as a result of the expropriating effect of the legislation. The Supreme Court of Canada held that the legislation resulted in expropriation and compensation was payable at common law. The Court held that goodwill, although intangible, was property of a business. ${ }^{83}$ The Court further held that goodwill was taken from Manitoba Fisheries and acquired by the Crown. ${ }^{84}$ With respect to compensation, Ritchie J. stated:

It will be seen that in my opinion the Freshwater Fish Marketing Act and the Corporation created thereunder had the effect of depriving the appellant of its goodwill as a going concern and consequently rendering its physical assets virtually useless and that the goodwill so taken away constitutes property of the appellant for

$80 \quad$ Ibid. at $162-63$.

81 Ibid. at 160-61 [footnotes omitted]. It is not exactly clear what Lord Pearce meant when suggesting that the U.S. Supreme Court was relying on the Fifth Amendment alone. The judgment of the Chief Justice in United States v. Caltex (Philippines), 344 U.S. 149 (1952), clearly purported to rely on the principal of "imminent peril" pursuant to the common law in applying the Fifth Amendment. Careful analysis of these two cases suggests that the English common law provides for greater property protection than the Fifth Amendment, where the issue of exercise of police powers is concerned. For a good discussion of the origins of the Fifth Amendment see Edward J. Sullivan \& Kelly D. Connor, "Making the Continent Safe for Investors - NAFTA and the Takings Clause of the Fifth Amendment of the American Constitution” (2004) 36 The Urban Lawyer 99.

82 [1979] 1 S.C.R. 101.

83 Ibid. at 108 .

$84 \quad$ Ibid. at 110 . 
the loss of which no compensation whatever has been paid. There is nothing in the Act providing for the taking of such property by the Government without compensation and as I find that there was such a taking, it follows, in my view, that it was unauthorized having regard to the recognized rule that "unless the words of the statute clearly so demand, a statute is not to be construed so as to take away the property of a subject without compensation., 85

It is important to note that even though the physical assets of Manitoba Fisheries were not taken, the Court found that its goodwill had been expropriated to the benefit of the Crown. It was not physical property that was found to be expropriated, but rather, goodwill.

In British Columbia v. Tener, ${ }^{86}$ the Supreme Court of Canada dealt with a claim of expropriation made in respect of a Crown coal lease. The surface of the area over which the lease was held was incorporated within a provincial park. Regulation of the park became more stringent over the years to the point that the Crown lessee started to be denied access to the park. The Supreme Court of Canada unanimously held that the denial of access to the park constituted expropriation. The Court was not unanimous, however, regarding the nature of the expropriation. The Court was in agreement that the Crown lease constituted a profit à prendre, but the minority judgment of Wilson J. held that denial of access resulted in the merger of the profit with the fee, thereby extinguishing the profit à prendre. ${ }^{87}$ The result, in Wilson J.'s view, was full expropriation of the Crown lease, which she would have directed be cancelled upon payment of compensation.

Justice Estey, speaking for the majority, held that the expropriation was only partial. He stated that

[t]he denial of access to these lands occurred under the Park Act and amounts to a recovery by the Crown in part of the right granted to the respondents in 1937. This acquisition by the Crown constitutes a taking from which compensation must flow. ${ }^{88}$

The result was that the Crown lease still existed and compensation for the expropriation had to account for the contingency that at some point, the Crown lessee may gain access to its minerals. ${ }^{89}$ Both Wilson and Estey JJ. agreed that the Crown lessee's loss was a result of a gain or benefit accorded to the Crown. Justice Wilson found that the value of the Crown estate had been enhanced because the profit reserved on the grant had been extinguished. Although Estey J.'s judgment maintained the continued existence of the Crown lease, he still concluded that the Crown benefited because its land (the park) had an enhanced value. ${ }^{90}$ Justices Wilson and Estey also agreed that the Crown could not rely on a reservation in the Crown lease to the effect that the grant was "subject to the laws for the time being in force."91 Regarding this possibility, Estey J. stated as follows: "It can hardly be (and it was not)

Ibid. at 118 [citations omitted]. [1985] 1 S.C.R. 533 [Tener].

Ibid. at 542 .

Ibid. at 563 .

Ibid. at 565 .

Ibid.

Ibid. at 536, 553. 
argued that the proviso in the grant authorized a compulsory taking without compensation for the purposes unrelated to the regulation of mining to the respondents' minerals."92

In Carrier Lumber Ltd. v. British Columbia ${ }^{93}$ the Crown forcefully relied on its reservation in the granting clause of a forest licence in an attempt to avoid paying compensation. In that case, Carrier Lumber Ltd. (Carrier) acquired a forest licence from British Columbia to cut 5 million cubic metres of wood. ${ }^{94}$ When Carrier was approximately half way through cutting its allotted wood, the First Nations began to protest that the licence had been issued without proper consultation. Unknown to Carrier, the Premier of British Columbia met with the Chiefs and promised that certain lands included in the forest licence would not be accessed without their consent. Because of this promise, government officials encouraged Carrier to enter into a joint venture arrangement with the First Nations. The First Nations were unwilling to enter into a joint venture agreement on terms acceptable to Carrier.

Following the issuance of Carrier's forest licence, the Forest $A c t^{95}$ and regulations had been amended. Provisions regarding stumpage fees and silviculture (tree planting) obligations were increased. Pursuant to these new legislative provisions, the province demanded that Carrier comply with the new silviculture regulations. Carrier did not do so in the time prescribed and its licence was suspended and later cancelled. The Court rejected the Crown's reliance upon the reservation in its grant. Justice Parrett stated:

The Crown then seeks, in their submissions, to rely on the legislation, subordinate legislation and policy decisions which were made well after the awarding of Forest Licence A20022. The linchpin for all of these submissions is article 15.03 of the Forest Licence, which provides that:

This licence is subject to the Forest Act.

The essence of this submission comes to little more than the assertion that the Crown can do no wrong, that in granting the Forest Licence it was explicitly, and to the knowledge of all subject to the provisions of the Forest Act. The submission in effect asserts the proposition that any legislative provision validly enacted amends the bargain between the parties and must be accepted by them.

As an example drawn at least in theory from the present case the imposition after the fact on a contractor of an entirely new silviculture obligation of $\$ 30,000,000$ or $\$ 60,000,000$ or $\$ 90,000,000$ if validly enacted can have no effect on the bargain between the parties.

With the greatest of respect, this is not a sound proposition in law. The Crown is itself a party which is subject to the common law of contracts in much the same fashion as any private party. In Journal Publishing Co. v. R., [1930] 4 D.L.R. 644 (Can. Ex. Ct.) at 649, the proposition was put in these words:

It follows therefore that in matters of contract the legal rights and liabilities of the Crown are substantially the same as those arising between subject and subject.

Ibid. at 554 .

(1999), 47 B.L.R. (2d) 50 (B.C.S.C.) [Carrier Lumber].

Ibid. at para. 21.

R.S.B.C. 1979 , c. 140 . 
The present case is complicated in part by the fact that the changes to the terms of Carrier's licence were brought about by the passage of amendments to the Forest Act and associated regulations.

The leading case on the power of the Crown to take possession of property without compensation is Attorney General v. De Keyser's Royal Hotel Ltd., [1920] A.C. 508 (U.K. H.L.). In this case, the British army, during World War I, required accommodation for its troops in London. It took over the hotel under the Defence of the Realm Regulations. The receiver of the hotel brought action for compensation. The House of Lords held the Crown liable to pay compensation. Lord Atkinson, at page 542, says:

Neither the public safety nor the defence of the realm requires that the Crown should be relieved of a legal liability to pay for the property it takes from one of its subjects. The recognized rule for the construction of statutes, is that, unless the words of the statute clearly so demand, a statute is not to be construed so as to take away the property of a subject without compensation. ${ }^{96}$

There are no cases which address the issue of expropriation in the context of an Alberta Crown oil sands lease, but there is a case that addresses principles of interpretation that should be applied to such a lease. In Goodwell, the Alberta Court of Appeal addressed the issue of whether an oil sands producer had to obtain the consent of the owner of natural gas rights in order to produce bitumen where such production would, incidentally, draw gas out of the gas cap. The oil sands lessee's wells were shut in by the regulator because no consent had been obtained from a Crown gas lessee in respect of lands that had been leased, and the Crown in respect of unleased lands. Justice Fruman commenced her decision with the following observations:

The Athabasca oil sands in northern Alberta have been known to exist since at least 1719, when Cree Indians reported "gum or pitch that flows out of the banks of the river.” Explorers such as Peter Fidler, Peter Pond, David Thompson and Alexander Mackenzie noted the tar deposits and 'bituminous fountains' near the Athabasca River. However, no attempts were made to tap these vast, visible resources until the early 1900's, when oilmen encountered a number of geological, technical, logistical and financial challenges in recovering the molasses-like bitumen.

In the intervening century, data obtained from thousands of wells drilled in the oil sands has led to Canada's ranking as second in the world in estimated proved oil reserves. However, the technology used to recover the bitumen in the oil sands continues to be complex, requiring new and difficult techniques and huge outlays of capital. Unfortunately, an economically and technologically challenging situation has been complicated

Goodwell, supra note 57 at paras. 440-45 [emphasis added]. The Court had to overcome another significant obstacle before it could award compensation. In the amending legislation that introduced the new silviculture obligations, the Crown had specifically excluded any liability for compensation. The legislation was very clear in this regard. Justice Parrett got around this exclusion by referring to art. 39 of the Magna Carta (Carrier Lumber, supra note 93 at paras. 488-93) and the law of fundamental breach as articulated by the Supreme Court of Canada in the case of Hunter Engineering v. Syncrude Canada $L t d$., [1989] 1 S.C.R. 426. He held that, like a case of fundamental breach in the law of contract, the breach here was so fundamental that the exclusion of compensation expressed in the legislation could not be relied upon (at para. 175). The result in the case supports the views of Monahan, supra note 4, in suggesting that the rule of law may impose limits on how far legislatures may go in extinguishing contract rights. 
by legal issues that result from the leasing strategy the Alberta government has used to develop the oil sands. ${ }^{97}$

Later in the judgment, she stated:

Retroactively changing the economics may compromise financial security, undermine investor confidence and potentially impair the exploitation of these resources. Therefore, in interpreting the terms of these overlapping hydrocarbon leases, we should, if possible, avoid an interpretation that diminishes the value of either lessee's interest. $^{98}$

Finally, in response to an argument that a requirement of production sharing agreements was a settled expectation, Fruman J.A. stated: "Such a restriction should either be plainly stated in the oil sands leases, and echoed in the permits and well licenses, or in an amendment to the Alberta energy legislation.",99

Interpreting the standard form of a Crown oil sands lease to allow either the Alberta government, by regulation, or the Alberta legislature, by amendment, to increase royalties has a far greater effect on changing the economics (and thereby compromising financial security and undermining investor confidence) than a requirement of a production sharing agreement prior to producing a gas cap. The language of a standard Alberta Crown oil sands lease states that the royalty "that is now reserved or may ... from time to time be prescribed" by legislation or regulations. It does not, however, state that if changes "from time to time" reduce the value of the estate granted, that the Crown will not be liable to pay compensation. Principles of Anglo-Canadian common law going back to the Magna Carta suggest that in order to avoid paying compensation where the value of an estate granted is reduced to the benefit of the Crown, there must be a clear intention stated that no compensation will be paid. The wording used must be clear to the point of there being no other possible interpretation but that compensation was not to be paid. There is nothing in a standard Crown oil sands lease or the MMA that approaches this level of clarity.

Prior to the NAFTA, there may have been no need for this level of clarity to keep the Alberta government's options open. The Crown's leasing practices could be complicated by legal issues because they could be resolved through the exercise of parliamentary supremacy by enacting future legislation expressly denying the right of compensation. In amending the $M M A$ to increase oil sands royalties, it will be open to the Crown to exclude expressly any liability for compensation as a result of the changes it makes. A very clear statement in the amending legislation could exempt the Province of Alberta from liability for compensation pursuant to Canadian expropriation law. The problem with relying on parliamentary supremacy to avoid compensation under Canadian expropriation law is that it may be interpreted as a concession when what is in fact taking place is expropriation. This in turn could be interpreted as an admission of liability for expropriation under the NAFTA. 
Before leaving Canadian expropriation law, the most recent Supreme Court of Canada case on the issue should be mentioned. In Canadian Pacific Railway v. Vancouver (City of),${ }^{100}$ the Canadian Pacific Railway Company (Canadian Pacific) sought compensation from the City of Vancouver as a result of a zoning bylaw that prohibited the railway from using its right of way over an abandoned rail line for residential and commercial development purposes. The bylaw did not affect the railway's ability to resume the use of its right of way for transportation.

Canadian Pacific argued that, although its title had not been taken by the City, the bylaw constituted a de facto taking. Chief Justice McLachlin summarized the Canadian law regarding de facto takings: "For a de facto taking requiring compensation at common law, two requirements must be met: (1) an acquisition of a beneficial interest in the property or flowing from it, and (2) removal of all reasonable uses of the property."101

The Supreme Court of Canada held that there was no de facto taking. The City of Vancouver did not get a beneficial interest in the land as a result of its restricted use, nor did the land become useless because the railway could continue to use the land as it had historically done. ${ }^{102}$ Finally, the Court said that even if there had been a de facto taking at common law, the Vancouver Charter, pursuant to which the bylaw was made, expressly denied any right of compensation. ${ }^{103}$

If the law of de facto takings were to be applied to Alberta's increased royalties, any compensation obligation may be greatly reduced. Many Crown leases, especially those associated with existing and approved projects, are extremely valuable. In these cases, it would be impossible to demonstrate that a Crown lessee's interests had been rendered useless. The Crown's risk of liability would be limited to the leases with marginal value, the development of which could not be justified at increased royalty rates. However, the analysis of oil sands tenure described above suggests that increased royalties would constitute more than a de facto taking because they would affect the legal title of both the Crown lessee and the Crown. They also involve physical taking of additional barrels of oil sands production from the Crown lessee. ${ }^{104}$

\section{AMERICAN TAKINGS LAW}

A brief review of American expropriation law is useful because the NAFTA expropriation provisions bear some resemblance to the U.S. constitutional protection given to property

2006 SCC 5, [2006] 1 S.C.R. 227 [Canadian Pacific Railway].

Ibid. at para. 30 [citations omitted].

Ibid. at paras. 32-33.

Ibid. at para. 36.

MMA, supra note 32, s. 34(3). The taking of a partial interest, where the Crown is the one that gets the interest taken, should constitute a direct expropriation rather than an indirect expropriation: see Jason L. Gudofsky, "Shedding Light on Article 1110 of the North American Free Trade Agreement (NAFTA) Concerning Expropriations: An Environmental Case Study” (2000) 21 Nw. J. Int'l L. \& Bus. 243 at 25557. 
rights. ${ }^{105}$ The Fifth Amendment to the U.S. Constitution (generally referred to as the "takings clause”) states:

No person shall ... be deprived of life, liberty, or property, without due process of law; nor shall private property be taken for public use, without just compensation. ${ }^{106}$

In Pennsylvania Coal v. Mahon ${ }^{107}$ the U.S. Supreme Court dealt with a situation similar to that addressed by the Supreme Court of Canada in the Tener case. Pennsylvania Coal had at one time owned the surface and the mineral rights to significant blocks of land in Pennsylvania. When disposing of its land, it reserved the right to coal, as well as the right to use and destroy so much of the surface of the land transferred as was necessary to access the coal, without liability for damages. This land was purchased by private land owners, as well as by towns and cities, for the purposes of construction of buildings and public infrastructure. In order to prevent subsistence of the surface, the State of Pennsylvania passed a law preventing mining of coal if it caused surface subsistence. Pennsylvania Coal challenged the law, arguing that it expropriated its reserved coal estate. Justice Holmes delivered the majority opinion of the Court, stating as follows:

\begin{abstract}
Government hardly could go on if, to some extent, values incident to property could not be diminished without paying for every such change in the general law. As long recognized, some values are enjoyed under an implied limitation, and must yield to the police power. But obviously the implied limitation must have its limits, or the contract and due process clauses are gone. One fact for consideration in determining such limits is the extent of the diminution. When it reaches a certain magnitude, in most if not in all cases, there must be an exercise of eminent domain and compensation to sustain the act. So the question depends upon the particular facts. The greatest weight is given to the judgment of the legislature, but it always is open to interested parties to contend that the legislature has gone beyond its constitutional power. ${ }^{108}$
\end{abstract}

In holding there was an expropriation, Holmes J. stated: "So far as private persons or communities have seen fit to take the risk of acquiring only surface rights, we cannot see that the fact that their risk has become a danger warrants the giving to them greater rights than they bought.”109

In Penn Central Transportation v. New York (City of), ${ }^{110}$ the U.S. Supreme Court considered a case similar to Canadian Pacific Railway. In Penn Central, the Grand Central Station had been declared a landmark site under New York City heritage regulations. A

See J. Martin Wagner, “International Investment, Expropriation and Environmental Protection” (1999) 29 Golden Gate U.L. Rev. 465.

U.S. Const. amend. V. The Fifth Amendment only applies to the federal government. Property protection was not initially given to Americans as against their state governments. The extension of property protection, as well as a number of other civil rights, was not accorded to Americans against their states until the enactment of the Fourteenth Amendment after the Civil War. Although the wording of the Fourteenth Amendment does not expressly mention takings without compensation, the Supreme Court of the U.S. effectively read this requirement into it in the case of Chicago, Burlington and Quincy Railroad v. Chicago, 166 U.S. 226 (1897). 260 U.S. 393 (1922).

108 Ibid. at 413 
development application had been submitted to construct a 55-storey office tower over top of Grand Central Station. The grounds for denying the application were summed up by the planning authority as follows: "to balance a 55-storey office tower above a flamboyant Beaux-Arts facade seems nothing more than an aesthetic joke." ${ }^{111}$ Upon denial of the development, Penn Central Transportation alleged that its property had been expropriated without compensation. The majority of the U.S. Supreme Court attempted to articulate the factors that the Court applied in takings cases. Justice Brennan stated:

[T]his Court, quite simply, has been unable to develop any "set formula” for determining when "justice and fairness" require that economic injuries caused by public action be compensated by the government.

[T] he Court's decisions have identified several factors that have particular significance. The economic impact of the regulation on the claimant and, particularly, the extent to which the regulation has interfered with distinct investment-backed expectations are, of course, relevant considerations.... So, too, is the character of the governmental action. A “taking” may more readily be found when the interference with property can be characterized as a physical invasion by government, ... than when interference arises from some public program adjusting the benefits and burdens of economic life to promote the common good. ${ }^{112}$

Penn Central Transportation attempted to argue that it had been deprived of its air rights. The Court rejected this argument on the basis that an owner could not "divide a single parcel [of property] into discrete segments” for the purposes of analyzing deprivation. ${ }^{113}$ The Court found that Penn Central Transportation's property had not been rendered valueless and in fact it continued to use the property as it had for the past 65 years. Further, even regarding air rights, the Court held that there was still value to these rights in at least two respects. First, it was not prohibited from using the air rights as long as its plans did not constitute "an aesthetic joke.” Second, the City's planning laws allowed for the transferring of planning rights from one property to another in the event of restrictions being placed on a landmark. Concerning investment-backed expectations, the Court noted that landmark status came with a property tax exemption and that designation as a landmark allowed Penn Central Transportation to not only make a profit with respect to the property, but to earn a “reasonable return” on its investment.

The Penn Central case does not come to a surprising result relative to the decision of the Supreme Court of Canada in Canadian Pacific Railway. Absent a physical taking or something akin to a physical taking, mere restrictions upon use do not render a property valueless relative to past uses and do not constitute expropriation under either American or Canadian law.

In Loretto v. Teleprompter Manhattan CATV Corp., ${ }^{114}$ the U.S. Supreme Court confirmed that there was an exception to the Penn Central analysis in the event of physical takings. In 
that case, the City of New York had granted Teleprompter, a cable franchise, permission to run television cables into apartments on payment of nominal compensation and reimbursement for any damages caused by installing the cables. Prior practice was for competitive cable television companies to offer apartment owners approximately 5 percent of the revenue generated from cable subscriptions. Apartment owners challenged the law as expropriation. The majority of the U.S. Supreme Court upheld the challenge. In doing so, Marshall J., speaking for the majority of the Court, stated:

In short, when the "character of the governmental action,” Penn Central, ... 438 U.S. 124 ... is a permanent physical occupation of property, our cases uniformly have found a taking to the extent of the occupation, without regard to whether the action achieves an important public benefit or has only minimal economic impact on the owner. ${ }^{115}$

In Lucas v. South Carolina Coastal Council, ${ }^{116}$ a sharply divided U.S. Supreme Court created a further categorical case of expropriation that also purported to bypass the Penn Central factors. In Lucas, a developer had purchased South Carolina beach lots. Before the owner could get a development permit, a zoning law was passed that prohibited construction of a residence on the lots. A majority of the U.S. Supreme Court suggested that in any case where property is rendered useless by state regulation, it would constitute a taking requiring compensation regardless of the compelling nature of the public interest the state was seeking to achieve. ${ }^{117}$ The only exception to this would be where the use being prohibited would otherwise constitute a private or public nuisance at common law. ${ }^{118}$

In the case of Tahoe-Sierra Preservation Council v. Tahoe Regional Planning Agency, ${ }^{119}$ the U.S. Supreme Court was once again sharply divided. This time, however, the balance of power shifted and the minority judges in Lucas became the majority in Tahoe. A CaliforniaNevada joint planning agency had frozen development around Lake Tahoe for three years. Although Tahoe did not overrule Lucas, it read extreme limitations into the Lucas decision. It limited Lucas' application to cases of “fee-simple title" where it could be shown that 100 percent of all economically beneficial uses had been eliminated in perpetuity. ${ }^{120}$ Situations of such permanent obliteration of all value as a result of regulation, as opposed to a physical taking, should be rare. The Court in Tahoe left the categorical exception of physical takings intact, stating:

The text of the Fifth Amendment itself provides a basis for drawing a distinction between physical takings and regulatory takings. Its plain language requires the payment of compensation whenever the government acquires private property for a public purpose, whether the acquisition is the result of a condemnation proceeding or a physical appropriation. But the Constitution contains no comparable reference to regulations that prohibit a property owner from making certain uses of her private property.

Ibid. at 434-35.

505 U.S. 1003 (1992) [Lucas].

Ibid. at 1027.

Ibid. at 1029.

535 U.S. 302 (2002) [Tahoe].

Ibid. at 330 . 
When the government physically takes possession of an interest in property for some public purpose, it has a categorical duty to compensate the former owner. ${ }^{121}$

The state of American takings law appears relatively clear in respect of direct expropriations. When it comes to indirect expropriations or regulatory takings, the courts have historically been sharply divided and it is extremely difficult to predict where it will land on any given fact situation.

\section{NORTH AMERICAN FREE TRADE AGREEMENT}

\section{A. Provisions of the North American Free Trade Agreement}

The NAFTA applies to "measures"122 of a "Party""123 adopted or maintained in respect of an "investment." 124 It is a common misconception that the NAFTA protection is limited to protecting the goods, services, investments, and investors of another party from discrimination relative to nationals. ${ }^{125}$ Prohibiting all types of discrimination and according national treatment is a large part of the NAFTA, but the NAFTA protections go beyond this, and in certain instances, accord investors of other NAFTA parties with absolute minimum standards of treatment, regardless of how the NAFTA party chooses to treat its own nationals. The primary example of this is the NAFTA provisions in respect of expropriation and compensation. Article 1110 of the NAFTA provides as follows:

1. No Party may directly or indirectly nationalize or expropriate an investment of an investor of another Party in its territory or take a measure tantamount to nationalization or expropriation of such an investment (“expropriation”), except:

(a) for a public purpose;

(b) on a non-discriminatory basis;

(c) in accordance with due process of law and Article $1105(1) ;{ }^{126}$ and

(d) on payment of compensation in accordance with paragraphs 2 through $6 .^{127}$

Ibid. at 321-22 [citations omitted].

Measures are broadly defined in NAFTA, supra note 16, art. 201 as including "any law, regulation, procedure, requirement or practice."

The parties are Canada, the U.S., and Mexico. The obligations assumed pursuant to the NAFTA extend not only to the federal governments of the parties, but also to their state and provincial governments, as expressly provided in art. 105.

Supra note 16, art. 1101.

See Schneiderman, supra note 27 at 535.

NAFTA, supra note 16, art. 1105(1) provides as follows: "Each Party shall accord to investments of investors of another Party treatment in accordance with international law, including fair and equitable treatment and full protection and security.”

Ibid., art. 1110. These provisions require compensation to be based upon fair market value as at the date of expropriation with payment to be made without delay. 
The most significant substantive difference between the protections afforded against expropriation under the NAFTA, relative to that which prevails in Canadian law, is that the NAFTA eliminates the use of parliamentary sovereignty as a means of avoiding payment of compensation for expropriation in respect of investments made by Americans and Mexicans in Canada. If legislation directly denying the right to compensation is passed, it will be effective as against Canadian investors, but it may highlight the fact that compensation will likely be owing to any American or Mexican investors who are affected by the expropriatory measure.

The second substantive difference between the NAFTA expropriation protection and that afforded by domestic law, applies to both Canada and the U.S. The NAFTA protects virtually every conceivable type of investment, going far beyond protecting property, whether real, personal, or intangible. The extent of this protection can be appreciated by reviewing para. (h) of the definition of "investment," which includes: "interests arising from the commitment of capital or other resources in the territory of a Party to economic activity in such territory."

In addition to these substantive differences, the NAFTA provides a significant procedural advantage over domestic expropriation law, namely, it permits investors to bring direct actions for damages against Canada, Mexico, and the U.S. pursuant to international commercial arbitration rules. ${ }^{129}$ For claims against Canada, investors have the option of bringing their claims pursuant to the Additional Facility Rules of the International Centre for Settlement of Investment Disputes, or the Arbitration Rules of the United Nations Commission on International Trade Law. ${ }^{130}$ These procedures generally provide for a threemember arbitration panel, with the investor appointing one arbitrator, the NAFTA party facing the claim appointing the other, and the two appointed arbitrators selecting a third. In these proceedings, the NAFTA party does not have the advantage of any special procedural or substantive protections that might be available to it through its own courts. It is also limited in its ability to exhaust claimants through trial and multiple appellate processes. International commercial arbitration puts the NAFTA parties and investors on an equal footing.

These are the obvious differences between expropriation law under the NAFTA and the laws of Canada and the U.S. Beyond this, it is not clear whether the NAFTA provides any greater protection through the scope of what constitutes "expropriation." The term expropriation is not defined in the NAFTA. The only guidance given as to what is meant by expropriation is the governing law provision of c. 11 , which indicates that disputes are to be decided in accordance with the NAFTA "and applicable rules of international law." ${ }^{131}$ The NAFTA arbitration tribunals have seen this as an indication that they are to look to the customary international law of expropriation in interpreting what is meant by expropriation under the NAFTA. As a practical matter, the customary international law of expropriation is of limited assistance because this body of international law has not yet been fully

$\begin{array}{ll}128 & \text { Ibid., art. } 1139 . \\ 129 & \text { Ibid., arts. 1116-17. } \\ 130 & \text { Ibid., art. 1120. } \\ 131 & \text { Ibid., art. 1131. }\end{array}$


developed. ${ }^{132}$ As a result, the NAFTA arbitration panels are the ones who have been advancing the development of the customary international law of expropriation. ${ }^{133}$ This should not be surprising given that Canada and the U.S. have the largest two-way trading relationship in the world. When one adds to this fact that both countries have extremely welldeveloped legal systems, it could have been predicted that investor-state commercial arbitration under the NAFTA would influence the development of international expropriation law. ${ }^{134}$

Before proceeding to a discussion of the NAFTA arbitration panel decisions and their interpretation of expropriation, it is interesting to note that arguments have been made that Canada's Crown share back-in on Canada lands introduced through the NEP constituted expropriation under customary international law. ${ }^{135}$ In many respects, Alberta's measures to increase oil sands royalties are more vulnerable to compensation claims than to the NEP Crown share back-in. In contrast to Alberta's measures, the Crown back-in on Canada lands did not apply to producing leases. Where the back-in was exercised on non-producing lands, it came with compensation for certain types of exploration expenses, and not insignificantly, the back-in was a working interest whereby the Crown would be at risk for its share of all future development costs. ${ }^{136}$ As far as the impact on an investor's legal rights or interests is concerned, Alberta's oil sands royalty increases have a far greater impact. In the case of the Crown share back-in, the derogation from the estate or interest was the result of carving out a working interest. In the case of Alberta royalties, the estate and interest of the Crown lessee is diminished by the reservation of a higher royalty.

The issue of whether the Crown share back-in constituted expropriation under customary international law was never resolved. The rules of customary international law would have required the U.S., on behalf of American oil companies, to bring Canada before the International Court of Justice. Diplomacy as between states often does not permit vindication of individual investor disputes. As suggested in the introduction to this article, the response of the U.S. to trade issues arising out of the NEP was likely to negotiate the CUSFTA and then the NAFTA. The question of whether measures such as those which will arise on Alberta's implementation of increased oil sands royalties will now stand to be tested under the NAFTA. The likelihood that they will be tested has been greatly increased because investors can now take direct action to initiate international commercial arbitration proceedings to counter measures that arguably constitute expropriation.

L. Yves Fortier \& Stephen L. Drymer, “Indirect Expropriation in the Law of International Investment: I Know It When I See It, or Caveat Investor” (2004) 19 ICSID Rev. 293 at 296.

John B. Fowles, "Swords Into Plowshares: Softening the Edge of NAFTA's Chapter 11 Regulatory Expropriations Provisions” (2005) 36 Cumb. L. Rev. 83 at 101.

Rudolf Dolzer, “Indirect Expropriations: New Developments?” (2002) 11 N.Y.U. Envtl. L.J. 64 at 6768.

Cecil J. Olmstead, Edward J. Krauland \& Diane F. Orentlicher, "Expropriation in the Energy Industry: Canada’s Crown Share Provision as a Violation of International Law” (1984) 29 McGill L.J. 439.

The actual economic impact of the Crown back-in was diminished as a result of the federal oil and gas tenure system whereby tenure was gained through work commitments, rather than through a bonus bid system as in Alberta. 


\section{B. North American Free Trade Agreement Arbitral Awards}

A number of NAFTA tribunal arbitral awards discussing the interpretation of expropriation under art. 1110 have now been issued. In this article, the cases have been broken down into three categories. The first category addresses allegations of contractual breaches. The second category deals with allegations of expropriation arising from commercial regulation. The final category of cases is those where the claims arose out of environmental regulations.

\section{CONTRACT BREACHES}

In Azinian v. United Mexican States, ${ }^{137}$ an American investor had obtained a concession contract to provide exclusive waste management services to a suburb of Mexico City. The contracting municipality was not pleased with the performance under the contract and conducted an investigation which disclosed that the American investor had made serious misrepresentations in order to secure the concession contract and was substantially in breach of a number of fundamental provisions. The municipality took action to cancel the contract. The American investor challenged the cancellation in Mexico, but was unsuccessful after three different levels of review. The Mexican courts held that the concession contract had been validly cancelled. The American investor brought a NAFTA claim arguing that the concession contract had been expropriated pursuant to art. 1110 .

The Tribunal held that a breach of contract could not itself constitute expropriation. ${ }^{138}$ What the investor would have had to show was that he was denied fundamental justice from the Mexican courts to the point of the actions of the Mexican courts being internationally unlawful. ${ }^{139}$

Waste Management v. United Mexican States ${ }^{140}$ once again involved a concession contract for waste management services, this time with the City of Acapulco. The difference between this case and Azinian was that it was the City of Acapulco that was in obvious breach of the contract. The City was chronically behind in paying certain invoices and refused to pay others. Although the Mayor had threatened to cancel the concession contract because of the complaints of residents about its exclusivity clause, the City did not cancel the contract. Instead, it was content to allow Waste Management to continue to perform without full payment. It was Waste Management which put an end to the concession contract. It initially instituted proceedings in Mexico to recover its losses. However, instead of following through with these domestic claims, Waste Management decided to forego domestic proceedings in Mexico and pursued a claim under the NAFTA.

(2000), 39 I.L.M. 537, (International Centre for Settlement of Investment Disputes) [Azinian].

Ibid. at para. 87.

Even if the NAFTA tribunal had been prepared to sit on appeal from the Mexican courts, the Claimants still would not have been successful because the tribunal made a finding of fact that " $[\mathrm{t}] \mathrm{he}$ evidence compels the conclusion that the Claimants entered into the Concession Contract on false pretences, and lacked the capacity to perform it”: ibid. at para. 33 .

(2004), 43 I.L.M. 967, (International Centre for Settlement of Investment Disputes) [Waste Management]. 
The Tribunal dismissed the claim, concluding that there had been no expropriation. Speaking to the threat made by the Mayor to cancel the concession contract, the Tribunal stated:

But even if a unilateral and unjustified change in the exclusivity obligation could have amounted to an expropriation, no legislative change was in fact made. The Claimant argued that this statement "effectively repealed the law" but the Tribunal does not agree. The Mayor was not purporting to exercise legislative authority or unilaterally to vary the contract. He was not intervening by taking some extra-legal action .... Individual statements of this kind made by local political figures in the heat of public debate may or may not be wise or appropriate, but they are not tantamount to expropriation unless they are acted on in such a way as to negate the rights concerned without any remedy. ${ }^{141}$

On the issue of the contractual breach, the Tribunal concluded:

[I]t is one thing to expropriate a right under a contract and another to fail to comply with the contract. Noncompliance by a government with contractual obligations is not the same thing as, or equivalent or tantamount to, an expropriation. In the present case the Claimant did not lose its contractual rights, which it was free to pursue before the contractually chosen forum. The law of breach of contract is not secreted in the interstices of Article 1110 of NAFTA. Rather it is necessary to show an effective repudiation of the right, unredressed by any remedies available to the Claimant, which has the effect of preventing its exercise entirely or to a substantial extent.

A failing enterprise is not expropriated just because debts are not paid or other contractual obligations are not fulfilled. The position may be different if the available legal avenues for redress are blocked or are evidently futile in the face of government intransigence. ${ }^{142}$

In the case of increased Alberta oil sands royalties, there are two types of contracts involved. The first is the Crown lease. Arguably, increasing royalties would not constitute a breach of the Crown leases. They have no specified royalties stated in them. The expropriatory measure would be the amendment to the royalty rates in the MMA.

The second type of contract is the Crown agreement. These agreements specify fixed royalty rates to be assessed under the Crown leases for a specified period of time. In the event that the Alberta government proceeds to breach the Crown agreements, Azinian and Waste Management suggest that such breaches would not constitute expropriation under the NAFTA. What would constitute expropriation is if the legislature proceeded to deny the opportunity to enforce the Crown agreements in Alberta courts. Under Canadian law, this can only be done by using clear language in the legislation denying any right of compensation for unilateral changes made to Crown agreements. Arguably, this is the only way Alberta could avoid liability for unilaterally changing the Crown agreements under Alberta law. If the Province of Alberta resorts to parliamentary supremacy in an attempt to relieve itself of the obligation to compensate for unilateral changes made to the Crown Agreements, there 
will be a strong case under the NAFTA that these actions constitute expropriation by eliminating the opportunity to vindicate contractual rights in Alberta courts.

\section{COMMERCIAL REgUlATION CASES}

Pope \& Talbot v. Canada ${ }^{143}$ was one of the first NAFTA cases to interpret art. 1110. In that case, a U.S. investor contended that Canada's export control regime instituted to implement a softwood lumber agreement with the U.S. constituted expropriation. The allegation was that the export controls limited the investor's exports and thereby limited profits from its investment. The investor defined its investment as the U.S. market share it had worked to establish. The Tribunal accepted that market share could constitute an investment. The issue was whether this investment had been expropriated pursuant to the NAFTA.

The investor admitted that the export control regime did not constitute either direct or indirect expropriation pursuant to international law. The investor argued that the NAFTA had extended the compensation obligation recognized by international law by including liability for measures that was "tantamount to expropriation.” In commencing its analysis, the Tribunal noted the investor's acknowledgment as follows: "First of all, there is no allegation that the Investment has been nationalized or that the Regime [the export control regime] is confiscatory.... Canada ... does not take any of the proceeds of company sales.” The Tribunal rejected the investor's argument, stating: "The Tribunal is unable to accept the Investor's reading of Article 1110. 'Tantamount' means nothing more than equivalent. Something that is equivalent to something else cannot logically encompass more." 144 Pope $\&$ Talbot is not particularly useful in determining whether an increase in oil sands royalties constitute expropriation, other than for the fact that the Tribunal did point out that Canada was not taking any proceeds from company sales.

In GAMI Investments v. United Mexican States, ${ }^{145}$ an American investor owned 14.18 percent of the shares in a Mexican sugar company. The Mexican company had its sugar mills in Mexico expropriated. In what was referred to as a derivative action, the American investor suggested that expropriation of the physical assets of the Mexican company was an indirect expropriation of its shares or share value. The Tribunal allowed the action to proceed on the basis that the American investor had standing, but dismissed the claim for expropriation because the shareholder could not link the expropriation of the assets of the Mexican company to an act of expropriation of its shareholding in that company. The Tribunal stated as follows:

The position then is this: GAMI [the U.S. investor] is entitled to invoke the protection of Article 1110 if its property rights (the value of its shares in GAM [the Mexican Sugar company]) were taken by conduct in breach of NAFTA. GAMI argues that such conduct was manifest in the Expropriation Decree. This Tribunal finds it likely that the Expropriation Decree was inconsistent with the norms of NAFTA. But Mexican conduct inconsistent with the norms of NAFTA is only a breach of NAFTA if it affects interests protected 
by NAFTA. GAMI's investment in GAM is protected by Article 1110 only if its shareholding was "taken."146

This case suggests that Americans with non-controlling shareholdings in Canadian companies will not be able to make successful NAFTA expropriation claims even when the investments of a Canadian company in which they hold shares have been expropriated. ${ }^{147}$

\section{ENVIRONMENTAL REGULATION CASES}

In Metalclad Corp. v. United Mexican States, ${ }^{148}$ Metalclad Corporation (Metalclad) was an American investor that had purchased a Mexican company through a wholly owned subsidiary. The Mexican company had been developing a hazardous waste landfill. It had already received federal approvals for construction of the landfill. As part of its due diligence in the share purchase process, Metalclad confirmed with Mexican federal authorities that all that it required to construct and operate the hazardous waste landfill were federal approvals. Specifically, the federal authorities told Metalclad that it did not require a municipal development permit. As part of its due diligence, Metalclad also spoke with the Governor of the State in which the hazardous waste landfill was to be constructed. It received assurances from him that the state was supportive of the project. On this basis, Metalclad completed its purchase of the Mexican company and commenced and completed construction of the hazardous waste landfill pursuant to the federal approvals that had been obtained for the project. During the course of construction, the local municipality insisted that all construction activity cease because a municipal construction permit was required that had not been sought. Metalclad consulted with federal officials who apparently again assured the company that a municipal construction permit was not required, but suggested that it should apply for one in order to maintain a friendly relationship with the municipality. Metalclad made the application and proceeded with its construction. On completion, Metalclad obtained a federal operating permit. When Metalclad attempted to open the landfill, demonstrators blockaded it. The municipality later denied the development construction permit application following Metalclad's failed attempt at opening the landfill. Metalclad brought a claim under the NAFTA, alleging among other things, expropriation pursuant to art. 1110. Shortly following the filing of the claim, the Mexican state government issued an ecological decree prohibiting the operation of the landfill.

The Tribunal commenced its analysis with a broad statement regarding what it believed could constitute expropriation pursuant to the NAFTA. The Tribunal stated:

Thus, expropriation under NAFTA includes not only open, deliberate and acknowledged takings of property, such as outright seizure or formal or obligatory transfer of title in favour of the host State, but also covert or incidental interference with the use of property which has the effect of depriving the owner, in whole or

Ibid. at para. 129 [emphasis in original].

In NAFTA, supra note 16, art. 139, "investment of an investor of a Party" is defined to include "an investment owned or controlled directly or indirectly.” This article also defines an investment to include an "enterprise," which includes a corporation. The result is that damage suffered by a local company can be claimed as long as the local company is owned or controlled by an investor from another NAFTA party. See Waste Management, supra note 140 at paras. 83-85.

(2001), 40 I.L.M. 36, (International Centre for Settlement of Investment Disputes) [Metalclad]. 
in significant part, of the use or reasonably-to-be-expected economic benefit of property even if not necessarily to the obvious benefit of the host State.

By permitting or tolerating the conduct of Guadalcazar in relation to Metalclad which the Tribunal has already held amounts to unfair and inequitable treatment breaching Article 1105 and by thus participating or acquiescing in the denial to Metalclad of the right to operate the landfill, notwithstanding the fact that the project was fully approved and endorsed by the federal government, Mexico must be held to have taken a measure tantamount to expropriation in violation of NAFTA Article 1110(1). ${ }^{149}$

The Tribunal held that, as a matter of Mexican law, the federal government had exclusive authority to approve the landfill. ${ }^{150}$ The Tribunal further held that the federal government's failure to prevent the municipality from thwarting the operation of the landfill constituted a breach of art. 1105, which also amounted to expropriation under art. $1110 .^{151}$

The Tribunal also found that there was another basis for finding expropriation had occurred. The Tribunal held that the issuance of the ecological decree by the state government barred the operation of the landfill, thereby constituting another act of expropriation. In making this finding, the Tribunal held that it did not have to decide or consider the motivation or the intent of the state in adopting the ecological decree. ${ }^{152}$

The Metalclad Tribunal decision was challenged by way of a judicial review application to the British Columbia Supreme Court. ${ }^{153}$ In Mexico v. Metalclad Corp. ${ }^{154}$ the British Columbia Supreme Court decided that the Tribunal had exceeded its jurisdiction with respect to its interpretation of art. 1105 of the NAFTA by reading transparency requirements from a provision outside of c. 11 into art. 1105. Since the finding of expropriation based on the controversy around the municipal development permit was related to a breach of art. 1105, the Court found this basis for expropriation could not be sustained. The Court held that the ecological decree provided an independent act of expropriation. With respect to the Tribunal's interpretation of the definition of expropriation, Tysoe J. stated as follows:

Ibid. at paras. 103-104. This broad statement of what could potentially constitute expropriation under the NAFTA caused a great deal of concern in both Canada and the U.S. It caused the U.S. Congress to insist that a form of the Calvo Doctrine provision be incorporated into trade legislation in an attempt to ensure that future U.S. trade agreements did not provide foreign investors in the U.S. with greater protection than Americans had under the Fifth Amendment. See Meg Kinnear \& Robin Hansen, "The Influence of NAFTA Chapter 11 in the BIT Landscape” (2005) 12 U.C. Davis J. Int'l L. \& Pol'y 101 at 107-109. Also see Marc R. Poirier, "The NAFTA Chapter 11 Expropriation Debate Through the Eyes of a Property Theorist” (2003) 33 Envtl. L. 851 at 912.

Metalclad, ibid. at para. 105.

Ibid. at para. 104. Article 1105(1) is set out in supra note 126. The Tribunal read into this provision a requirement that NAFTA parties must always be transparent, and found that this was breached by the federal government because of inconsistent statements made regarding the applicability of municipal development permit requirements at different points in time.

Ibid. at paras. 109-11.

Pursuant to the additional facility rules of the International Centre for Settlement of Investment Disputes, challenges to the process adopted by an arbitration tribunal and the jurisdiction of the arbitration tribunal to proceed are to be brought to the domestic courts of the jurisdiction in which the arbitration proceeds. The site of the Metalclad arbitration was Vancouver.

2001 BCSC 664, 89 B.C.L.R. (3d) 359. 
The Tribunal gave an extremely broad definition of expropriation for the purposes of Article 1110 . In addition to the more conventional notion of expropriation involving a taking of property, the Tribunal held that expropriation under the NAFTA includes covert or incidental interference with the use of property which has the effect of depriving the owner, in whole or in significant part, of the use or reasonably-to-be-expected economic benefit of property. This definition is sufficiently broad to include a legitimate rezoning of property by a municipality or other zoning authority. However, the definition of expropriation is a question of law with which this Court is not entitled to interfere under the International CAA. ${ }^{155}$

In response to an argument that the Tribunal had not considered the issue of the need for environmental protection, Tysoe J. stated:

Counsel for Mexico further says that the Tribunal did not make reference to Article 1114(1) of the NAFTA, which reads as follows:

Nothing in this Chapter shall be construed to prevent a Party from adopting, maintaining or enforcing any measure otherwise consistent with this Chapter that it considers appropriate to ensure that investment activity in its territory is undertaken in a manner sensitive to environmental concerns.

Although the Tribunal did not mention Article 1114(1) in connection with the Ecological Decree, it did comment on the Article earlier in the Award. It pointed out that the conclusion of the Convenio and the issuance of the federal permits showed that Mexico was satisfied that Metalclad's project was consistent with, and sensitive to, environmental concerns. In any event, any error by the Tribunal in this regard is not patently unreasonable. ${ }^{156}$

The Metalclad decision has received more attention than any other NAFTA case to date. Most of the commentary has related to the extremely broad scope of the Tribunal's interpretation of what can constitute expropriation. ${ }^{157}$ The general statement made by the Tribunal describing what was meant by expropriation is admittedly broad. As Tysoe J. noted, the interpretation may go beyond domestic law in Canada and the U.S. It also likely goes beyond customary international law. However, this statement cannot be read in isolation. It has to be considered within the context of the specific facts that the Tribunal was considering. Based on the facts found by the Tribunal, it would be surprising if a court applying the domestic law of expropriation in either Canada or the U.S. did not arrive at the same conclusion as the Tribunal. These facts include the following:

- Metalclad had a reasonable expectation that it had all of the approvals it required to construct and operate its landfill and proceeded with a substantial investment in completing construction;

- as a matter of Mexican law (which is also a finding of fact made by the Tribunal), Metalclad had all of the approvals that it required, including environmental approvals that were issued based on the conclusions of the federal Mexican environmental

$155 \quad$ Ibid. at para. 99.

$156 \quad$ Ibid. at para. 104.

157 See e.g. Chris Tollefson, "Metalclad v. United Mexican States Revisited: Judicial Oversight of NAFTA's Chapter Eleven Investor-State Claim Process” (2002) 11 Minn. J. Global Trade 183; Williams, supra note 26; Dolzer, supra note 134. 
authorities that the landfill could be constructed and operated in an environmentally sound manner; and

- an environmental decree had been issued following completion of the construction of the landfill, which barred it from ever operating.

When one considers that the NAFTA protects investments and the investment in this case was the landfill and not just the land on which it was built, the Tribunal's decision is not at all inconsistent with the Supreme Court of Canada's decision in Tener. Based on the U.S. Supreme Court's decisions in both Lucas and Tahoe, it would not be surprising for a U.S. court to find a taking under the Fifth Amendment.

The most important aspect of Metalclad is neither the statement of expropriation law nor the conclusions reached, of which neither is surprising. What Metalclad does emphasize, though, is that in international commercial arbitration, there can be findings of fact and interpretations of law that one strongly disagrees with, but has little recourse to challenge. This is the reality of commercial arbitration both domestically and internationally. NAFTA parties have no appeals like they do from decisions of domestic courts. ${ }^{158}$

In S.D. Myers v. Canada, ${ }^{159}$ the investor was an American company that had hazardous waste destruction facilities in the U.S. These facilities were capable of destroying polychlorinated biphenyls (PCBs). The U.S. Environmental Protection Agency (EPA) had closed the border to all imports of PCBs into the U.S., including those from Canada. S.D. Myers invested heavily in getting the U.S. border opened up to PCB imports from Canada. S.D. Myers incorporated a Canadian subsidiary to market its PCB destruction services to Canadian companies in anticipation of being able to export the PCBs to the U.S. for destruction once the border was opened. On the eve of the EPA opening the border to Canadian PCBs, the Canadian government implemented an export ban on PCBs. This measure was the result of intensive lobbying by two Canadian companies, one from Alberta and one from Quebec. The Alberta company had the only Canadian facility capable of destroying PCBs and the Quebec company was in the process of working on its own facility. The federal government's ban on PCB exports was, at least in part, motivated by a concern that opening the border could affect the economic viability of Canadian PCB destruction capacity. This was a concern because the federal government believed the public interest would be compromised if Canadian facilities were rendered uneconomic because of an open border.

The export ban only lasted for 18 months. When it was lifted, S.D. Myers was able to export some PCBs. S.D. Myers claimed a substantial financial loss during the period of the

158 If the parties do not like the interpretation given to c. 11 by tribunals, the Free Trade Commission under the NAFTA, made up of trade representatives of each of the parties, can issue interpretive notes with prospective effect that will be binding on future tribunals pursuant to art. 1131.2 of the NAFTA. Canada has apparently pursued the issuance of an interpretive note restricting the scope of art. 1110, but has been unable to secure the support of Mexico. See David A. Gantz, "Potential Conflicts Between Investor Rights and Environmental Regulation Under NAFTA’s Chapter 11” (2001) 33 Geo. Wash. Int'l L. Rev. 651 at 686; Gudofsky, supra note 104 at 303-305. 
border closure and argued that this loss was the result of the export ban, which constituted a measure tantamount to expropriation under art. 1110 of the NAFTA.

The Tribunal concluded that the export ban was a regulatory measure that did not constitute expropriation pursuant to the NAFTA. The Tribunal set out the following interpretation principles in relation to expropriation:

\begin{abstract}
The term "expropriation" in Article 1110 must be interpreted in light of the whole body of state practice, treaties and judicial interpretations of that term in international law cases. In general, the term “expropriation” carries with it the connotation of a "taking” by a governmental-type authority of a person’s "property" with a view to transferring ownership of that property to another person, usually the authority that exercised its de jure or de facto power to do the "taking."160
\end{abstract}

The Tribunal went on to say that, although regulatory measures were unlikely to constitute expropriation under art. 1110, it would "not rule out that possibility." 161 The Tribunal wrote:

Expropriations tend to involve the deprivation of ownership rights; regulations a lesser interference. The distinction between expropriation and regulation screens out most potential cases of complaints concerning economic intervention by a state and reduces the risk that governments will be subject to claims as they go about their business of managing public affairs.

An expropriation usually amounts to a lasting removal of the ability of an owner to make use of its economic rights although it may be that, in some contexts and circumstances, it would be appropriate to view a deprivation as amounting to an expropriation, even if it were partial or temporary. ${ }^{162}$

In concluding that there was no expropriation in this case, the Tribunal noted: "CANADA realized no benefit from the measure. The evidence does not support a transfer of property or benefit directly to others. An opportunity was delayed."163

As discussed earlier in this article, the proposed increases to Alberta's oil sands royalties are not being implemented as regulatory measures. The entire purpose behind the royalty increases is for the Alberta Crown to realize a financial benefit. There is a transfer of property from Crown oil sands lessees back to the Crown. Alberta's measures to increase its royalty take appears to come within the definition of expropriation provided by the Tribunal in S.D. Myers.

In Methanex Corp. v. United States of America, ${ }^{164}$ the investor was a Canadian producer of a fuel additive called methyl tertiary butyl ether (MTBE). California banned MTBE because it contaminated ground water as a result of leaking underground storage tanks (USTs) at filling stations. California favoured ethanol as an environmentally preferable fuel additive. Methanex Corporation (Methanex) argued that the concern for ground water

Ibid. at para. 280. The Tribunal did, however, acknowledge that rights other than property rights could be expropriated (at para. 281).

Ibid. at para. 281.

Ibid. at paras. 282-83.

Ibid. at para. 287.

(2005), 44 I.L.M. 1345, (NAFTA Ch. 11 Arbitral Tribunal) [Methanex]. 
contamination was a subterfuge. It said that California could have solved the ground water problem by solving the problem of leaking USTs, which would have also addressed other contaminates in gasoline, such as benzene, being released into the environment. Methanex contended that fixing USTs was environmentally preferable and far less expensive than replacing MTBE with ethanol as a fuel additive. Methanex alleged that the real reason California banned MTBE was because of the American ethanol lobby. Methanex suggested that one American company in particular had exercised undue influence over the Governor of California during an election campaign and that political contributions influenced the Governor's decision to ban MTBE. Based on these allegations, Methanex argued that California had effectively expropriated its share of the California fuel additives market and transferred it to ethanol producers. This, Methanex submitted, was tantamount to expropriation resulting in the requirement to pay compensation pursuant to art. 1110 of the NAFTA.

Methanex failed to prove any of its allegations. The MTBE ban was found to be implemented based on reasonable scientific evidence developed in response to environmental concerns that were held in good faith. In finding that there was no expropriation, the Tribunal stated:

\begin{abstract}
In this case, there is no expropriation decree or a creeping expropriation. Nor was there a "taking" in the sense of any property of Methanex being seized and transferred, in a single or a series of actions, to California or its designees. Insofar as Methanex can make a claim under Article 1110(1), it is not a claim for nationalization or expropriation, simpliciter, but for “measures tantamount to expropriation”. Thus, Methanex must establish that the California ban was tantamount to expropriation, within the meaning of Article 1110 of NAFTA. ${ }^{165}$
\end{abstract}

The Tribunal would have been willing to find an act tantamount to expropriation if Methanex could have demonstrated either intentional discrimination against it, or that specific commitments had been made to it by the government. The Tribunal stated:

\begin{abstract}
In the Tribunal's view, Methanex is correct that an intentionally discriminatory regulation against a foreign investor fulfils a key requirement for establishing expropriation. But as a matter of general international law, a non-discriminatory regulation for a public purpose, which is enacted in accordance with due process and, which affects, inter alios, a foreign investor or investment is not deemed expropriatory and compensable unless specific commitments had been given by the regulating government to the then putative foreign investor contemplating investment that the government would refrain from such regulation. ${ }^{166}$
\end{abstract}

The Methanex decision is interesting because of its suggestion that reasonable expectations may be determinative of whether regulatory measures constitute expropriation. In a case of regulatory measures, where there is no taking or transferring of property to government, Methanex suggests that specific commitments would have to have been made by the government to refrain from certain regulatory measures that would affect the value of

165 Ibid. at Part IV, c. D, para. 6.

166 Ibid. at Part IV, c. D, para. 7. It is interesting to note that the Tribunal's conclusion that discrimination against a foreign investor could constitute an otherwise valid act of expropriation is inconsistent with both S.D. Myers, supra note 159, and Feldman v. Mexico (2003), 42 I.L.M. 625, (International Centre for Settlement of Investment Disputes). 
an induced investment. In the case of Alberta's proposed increase to oil sands royalties, it could be difficult for foreign investors to show that the Alberta government made specific commitments not to increase royalties, other than those made in Crown agreements. But this is likely not the test that should be used in cases of direct expropriation where the government takes property from the investor. In such cases, the international customary law of expropriation, as incorporated through the NAFTA, should arguably reflect the AngloCanadian common law. If a government intends to take the property of an investor without compensation, it should be the government's obligation to make this very clear to the investor, so the investor understands that a taking may occur without compensation. The Alberta Crown should not be able to point to a reservation clause in a standard Crown lease and suggest that, in making an investment based on the lease document, the investor agreed that the Crown could unilaterally adjust royalties at its pleasure to a level that it considered fair any time it wanted and as often as it wanted. Had the Crown made such an express representation in its reservation clause (to the effect that the amount of the royalty would fall within its complete, unfettered discretion and no compensation would be payable for royalty adjustments regardless of the extent of their impact on the value of the investments made in and based upon Crown leases), Alberta's oil sands would not likely have seen the magnitude of investment it has experienced. In the case of direct takings, very clear representations should be required for governments to avoid liability for compensation, rather than to attract it.

Before leaving Methanex, reference should be made to the international arbitration decision the Tribunal relied on in advancing a doctrine of legitimate or reasonable expectations. The Tribunal cited the case of Revere Copper and Brass v. Overseas Private Investment ${ }^{167}$ as authority for specific commitments grounding a claim in expropriation. ${ }^{168}$ Revere Copper is extremely complicated and must be approached with a great deal of caution. Most of the complexities arise from the fact that the Tribunal in that case was not applying the definition of expropriation pursuant to customary international law. Instead, Revere Copper and Brass Incorporated (Revere Copper), was insured under a policy of insurance that set out a very specific definition of expropriation that did not track what is commonly understood as expropriation under international law. In that case, the Tribunal was applying a definition of expropriation that included measures "preventing the Foreign Enterprise from exercising effective control over the use or disposition of a substantial portion of its property." 169 Revere Copper had opened a bauxite mine in Jamaica pursuant to an agreement with the Government of Jamaica whereby the Government undertook not to increase taxes. In negotiating this commitment, the chief negotiator for the Government made it clear to Revere Copper that he could not make any agreement that would bind future legislative action and that any commitment not to increase taxes could only be a good faith commitment such that the Government "would not be likely to repudiate this undertaking."170 Revere Copper insisted on the commitment and received it. Years later, the Government proceeded to breach the commitment by imposing a 20 percent gross production tax on bauxite. Revere Copper sued the Government, but the Supreme Court of Jamaica held that 
the commitment not to increase taxes was void ab initio because ministers of the Government could not fetter the sovereignty of Parliament to legislate with respect to taxation. Revere Copper then made a claim against its insurers. The majority of the Tribunal held that the breach of the commitment constituted expropriation under the insurance policy. In coming to this conclusion, the majority stated: "Admittedly Parliament could at any time legislate with respect to taxes and thus override contracts with private parties. It could not, however, deprive such parties of compensation, if the circumstances justified the payment of compensation under international law principles. In our view, such circumstances existed in this case." ${ }^{171}$

The Arbitration Tribunal had earlier suggested that if the Government of Jamaica wanted to avoid liability in the event of legislative changes, it could have done so without breaching international law by providing for this in its agreement. The majority stated as follows:

If the parties had intended to preserve the Government's legislative freedom without the consequences under international law of violating its commitments, they could have done so in the Agreements entered into with the aluminum companies in 1956, 1966 and 1967. They did not do so. The 1957 commitments were allowed to stand unaltered for seventeen years, to be renewed and amplified in 1966 and 1967, and the latter to remain in effect for eight and seven years respectively. ${ }^{172}$

In addition to the complication arising from the unique definition of expropriation, Revere Copper is further complicated by the lack of clarity as to whether the new tax imposed was a regulatory measure (that is, general taxation), or if the tax itself could be considered an act of expropriation. The majority of the arbitrators agreed with the dissent that the tax "was not confiscatory." ${ }^{173}$ What is troublesome about this finding is that the dissent had relied upon the U.S. Supreme Court's decision in Sunshine Anthracite Coal v. Adkins. ${ }^{174}$ A closer review of that case suggests that the tax there was found to be valid based on the conclusion that it was a regulatory tax imposed for the purposes of enforcing a cooperative marketing scheme and not a revenue tax imposed for the purposes of raising money from a specific industry. The important point is that specific taxation measures can be confiscatory and constitute expropriation under both customary international law and the NAFTA.

\section{TAX VS. ROYALTY}

If a claim is being made for compensation as a result of expropriation pursuant to art. 1110 of the NAFTA as a result of the application of "taxation measures," the NAFTA requires that before the claim can proceed through arbitration, the tax authorities of the jurisdiction of the investor and the jurisdiction responsible for the taxation measures must be given an opportunity to opine on whether the measure complained of is expropriation. If they agree that the measure is not expropriation, the matter cannot proceed to arbitration. ${ }^{175}$ Taxation measures are not defined in the NAFTA other than to indicate what they do not include. ${ }^{176}$

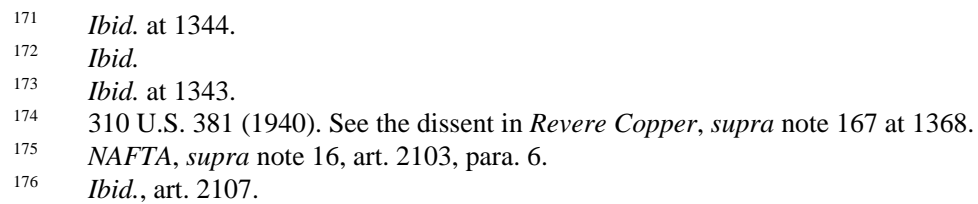


Based on the analysis set out above, under Canadian law, the proposed increase in oil sands royalties would likely not constitute a tax. Any investor commencing arbitration may face a preliminary jurisdictional issue to determine the exact nature of the measures which are used to increase Alberta's oil sands royalties. However, making such a challenge may be unwise. Initiating the challenge may be an implied admission that there is concern that the measure in fact constitutes expropriation. Further, any such challenger could run the risk that the U.S. would not agree. Presumably, before making such a jurisdictional challenge, Canada would seek the assurance of the U.S. that it believed that the measure involved constituted taxation and did not amount to expropriation. ${ }^{177}$

\section{CONCLUSION}

Rising world oil prices have enticed governments around the world to increase the economic rent demanded on the production of their oil and gas resources. The Alberta government has announced an intention to follow suit by increasing royalties on all oil sands production, irrespective of its vintage. This is the first time since Canada entered into the NAFTA that a Canadian government has tried to capture additional value in an attempt to get what it believes to be its fair share of oil production. The NAFTA has arguably created a form of quasi-constitutional property protection for American and Mexican investors in Canada, which does not allow Canadian governments and legislators to expropriate without compensation. It may still be possible to impose this type of expropriation on Canadian investors, just not their American and Mexican counterparts. Alberta's oil sands leasing practices may have been effective when Alberta exercised more or less complete sovereignty over its resources. Before the NAFTA, ambiguities could be clarified through subsequent legislation and responsibility for compensation could be expressly disclaimed. It appears that Alberta did not adapt its Crown leasing practices to make it clear that the grants it makes are subject to an absolute and unfettered right to increase royalties without compensation in a post-NAFTA world. In the absence of a clear reservation to this effect, it may well be reasonable for oil sands investors to demand compensation. Under the NAFTA, a very good case can be made for compensation to recover the loss in value to oil sands investments that would result from increased royalties proposed by the Government of Alberta. The answer to the multi-billion dollar question posed by this article is: Yes we can! But, if we do, the Government of Canada may have to pay very large NAFTA awards to a lot of American oil companies. 